Article

\title{
Assessment and Inter-Comparison of Multi-Source High Spatial Resolution Evapotranspiration Products over Lancang-Mekong River Basin, Southeast Asia
}

\author{
Houbing Chen ${ }^{1,2}\left(\mathbb{D}\right.$, Palingamoorthy Gnanamoorthy ${ }^{3}$, Yaoliang Chen ${ }^{1,2, * \mathbb{D}}$, Lamin R. Mansaray ${ }^{4} \mathbb{D}$, \\ Qinghai Song ${ }^{3}$, Kuo Liao ${ }^{5}$, Aoni Shi ${ }^{1,2}$, Ganlin Feng ${ }^{1,2}$ and Chenna Sun ${ }^{3}$
}

Citation: Chen, H.; Gnanamoorthy, P.; Chen, Y.; Mansaray, L.R.; Song, Q.; Liao, K.; Shi, A.; Feng, G.; Sun, C. Assessment and Inter-Comparison of Multi-Source High Spatial Resolution Evapotranspiration Products over Lancang-Mekong River Basin,

Southeast Asia. Remote Sens. 2022, 14, 479. https://doi.org/10.3390/ rs14030479

Academic Editors: Praveena Krishnan and Shusen Wang

Received: 11 December 2021

Accepted: 18 January 2022

Published: 20 January 2022

Publisher's Note: MDPI stays neutral with regard to jurisdictional claims in published maps and institutional affiliations.

Copyright: (C) 2022 by the authors. Licensee MDPI, Basel, Switzerland. This article is an open access article distributed under the terms and conditions of the Creative Commons Attribution (CC BY) license (https:// creativecommons.org/licenses/by/ $4.0 /)$.
1 Fujian Provincial Key Laboratory for Subtropical Resources and Environment, Fujian Normal University, Fuzhou 350007, China; qsx20201145@student.fjnu.edu.cn (H.C.); qsx20211222@student.fjnu.edu.cn (A.S.); qsx20211221@student.fjnu.edu.cn (G.F.)

2 School of Geographical Sciences, Fujian Normal University, Fuzhou 350007, China

3 CAS Key Laboratory of Tropical Forest Ecology, Xishuangbanna Tropical Botanical Garden, Chinese Academy of Sciences, Mengla 666303, China; gnanamoorthy@xtbg.ac.cn (P.G.); sqh@xtbg.ac.cn (Q.S.); sunchenna@xtbg.ac.cn (C.S.)

4 Laboratory of Remote Sensing and GIS, Institute of Geography and Development Studies, School of Environmental Sciences, Njala University, Njala Campus, PMB, Freetown 1313, Sierra Leone; lamin.mansaray@njala.edu.sl

5 Wuyishan National Climatological Observatory, Wuyishan 354200, China; liaok@cma.gov.cn

* Correspondence: chenyl@fjnu.edu.cn; Tel.: +86-0591-8436-5214

\begin{abstract}
Evapotranspiration (ET) plays a crucial role in water balance within the global hydrological cycle. Timely assessment of ET products can provide the scientific basis for quantitative analysis of hydrological cycle processes and water resources assessment. In this paper, four high spatial resolution remote sensing ET products-the Moderate-resolution Imaging Spectroradiometer global terrestrial evapotranspiration product (MOD16), the ET product based on Penman-Monteith-Leuning equation version 2 (PML-V2), the ET product based on the Breathing Earth System Simulator (BESS) and the ET product of the Global LAnd Surface Satellite (GLASS) - were firstly assessed using the eddy covariance (EC) of different vegetation types in the Lancang-Mekong River Basin (LMRB). To fully assess the performances of these four products, spatiotemporal inter-comparisons and literature comparisons were also conducted across different climatic zones. The results are summarized as follows: (1) MOD16 does not perform well as compared to the other three products, with its Root Mean Square Error (RMSE) being higher than GLASS, PML-V2 and BESS, which are approximately $0.47 \mathrm{~mm} / 8$-day, $0.66 \mathrm{~mm} / 8$-day, and $0.90 \mathrm{~mm} / 8$-day, respectively; (2) the performance of each product varies across different vegetation types, and even within the same climate zone. PML-V2 performs best in evergreen broadleaf forests, BESS performs best in deciduous broadleaf forests and croplands, and GLASS performs best in shrubs, grasslands and mixed vegetation; (3) each product can well reflect the spatial difference brought by topography, climate and vegetation over the entire basin but all four ET products do not show either a consistent temporal trend or a uniform spatial distribution; (4) ET ranges of these four products over LMRB are consistent with previous literature in evergreen broadleaf forests, deciduous broadleaf forests, needleleaf forests and mixed forests in other regions with the same climate zones, but they show great differences in croplands, grasslands and shrubs. This study will contribute to improving our understanding of these four ET products in the different climatic zones and vegetation types over LMRB.
\end{abstract}

Keywords: evapotranspiration; accuracy assessment; Lancang-Mekong; river basin; eddy covariance; literature comparison 


\section{Introduction}

Terrestrial evapotranspiration (ET) is an important biophysical process in the landatmosphere system. As the second largest component of the global hydrological circle, it returns around $60-70 \%$ of precipitation to the atmosphere [1]. However, it is also one of the most uncertain components in the global water cycle [2-4]. Thus, accurately estimating ET is necessary for better quantification and allocation of water resources, which is of great significance to the sustainable utilization and management of global water resources in an era of growing climate change. Generally, the Penman-Monteith (PM) algorithm and the Priestley-Taylor (PT) algorithm are the two most commonly used methods for estimating ET, though the two algorithms have been proposed for more than four decades [5-10]. Extensive studies have been conducted to improve the PM algorithm from different aspects, such as stomatal conductance [7], soil moisture [10], temperature difference between day and night $[7,10,11]$, etc. However, to date, accurate estimation of actual ET at regional scales is still challenging [12].

In general, the methods for estimating regional ET can be grouped into four categories: upscaling of observed ET data, basin ET estimation based on the water balance theory, meteorological-data-derived ET and remote-sensing-data-derived ET. Although measurements such as the evaporator, scintillometer, Bowen ratio measuring system and flux tower with eddy covariance can provide accurate and dense vapor exchange at site and local scales, upscaling the observed ET to meet the accuracy demand at regional and global scales is hard [13]. Firstly, footprints of these measurements are rather small to represent a regional extent. Additionally, regions covered by enough ET measurements for various land cover types are very limited around the globe due to the expensive cost of instrument installation and maintenance. Actual ET estimation based on the water balance theory can provide an accurate regional result using measured precipitation and runoff datasets [14]. However, it cannot provide gridded ET results which may be more needed in water management, such as irrigation and reservoir operations. The meteorological-data-derived methods simulate actual ET based on robust physical mechanism models, such as the aerodynamic algorithm, the PM algorithm and the PT algorithm. The aerodynamic model dynamically integrates atmospheric water demand (i.e., vapor pressure deficit), and air and plant constraints (i.e., canopy resistance and aerodynamic resistance) [15]. The PM model calculates ET based on the principle of energy balance and water vapor transmission, and fully considers atmospheric physics and vegetation physiological characteristics $[5,11,16,17]$. The PT model is a simplified PM algorithm, which uses a dimensionless coefficient (0-1.26) instead of the complicated surface resistance and aerodynamic resistance in PM model [18,19]. These ET algorithms usually require meteorological forcing data with high temporal resolution, such as European Centre for Medium-Range Weather Forecasts Re-Analysis (ERA) interim, Climatic Research Unit (CRU) reanalysis, a Global Land Data Assimilation System (GLDAS) dataset, Reanalysis datasets from the National Centers for Environmental Prediction and the National Center for Atmospheric Research (NCEP/NCAR), and Global Modeling and Assimilation Office Modern-Era Retrospective analysis for Research and Applications (GMAO-MERRA). However, subjected to the coarse spatial resolution of these meteorological forcing data, the spatial resolution of their derived ET is also coarse. Remotely sensed imagery, with its extensive data archive at much lower cost and higher spatial resolution, has been extensively applied for ET estimation at regional scales. The Surface Energy Balance (SEB) model and the surface temperature-vegetation index triangle model (Ts-VI) are also often used in remote-sensing-derived ET calculation in addition to the PM and PT algorithms [20,21]. Meanwhile, remote-sensing-derived ET can also provide a relatively higher temporal resolution at daily or even shorter time intervals. At present, a good number of remote-sensing-derived ET products are available at global scales, such as the water balance (WB) ET product $\left(0.5^{\circ}\right)$ developed by Zeng [22], the Global Land Evaporation Amsterdam Model (GLEAM) $\left(0.25^{\circ}\right)$ product $[23,24]$, the ET product developed by Raoufi and Beighley (2017) which derived from remotely sensed land surface temperature $\left(0.05^{\circ}\right.$ and $\left.0.25^{\circ}\right)$ [6], the Penman-Monteith-Leuning ET product 
(PML) $\left(0.5^{\circ}\right)$ [25], the Moderate-resolution Imaging Spectroradiometer global terrestrial evapotranspiration product (MOD16) (500 m) [11,26], the ET product based on the PenmanMonteith-Leuning equation version 2 (PML-V2) $(500 \mathrm{~m})$ [7,9], the ET product based on the Breathing Earth System Simulator (BESS) $(1 \mathrm{~km})$ [27], the ET product of the Global LAnd Surface Satellite (GLASS) $(1 \mathrm{~km})$ [28], etc. Among these remote sensing ET products, quite a few can provide a relatively high spatial and temporal resolution, such as MOD16, PML-V2, BESS, and GLASS.

Although these remote-sensing-derived ET products were all globally validated by their developers, they are still subject to further assessment before their application in a given region owing to several reasons [29,30]. Firstly, flux sites used in global validation are limited. For example, the number of flux sites used in the global validation of BESS, MOD16, PML-V2, and GLASS is 33, 46, 95, and 120, respectively. Secondly, it was not feasible to focus on a certain region during the global validation of these actual ET products. Studies have been conducted extensively to compare and assess different ET products at regional and local scales [31-33]. Nevertheless, there is a lack of consistency in the performance of ET products across different geographic regions [34,35]. For example, Khan et al. [36] compared the performances of MOD16, GLDAS ET and GLEAM in East and Southeast Asia, and found that the deviation of ET products is about 1.5-5.5 mm/8-day, and GLDAS shows lower uncertainties. Zhao et al. [37] assessed ET products from Australia's Commonwealth Scientific and Industrial Research Organization (CSIRO), GLDAS, TerraClimate and MOD16 over the Murray-Darling Basin in Australia, and found that the ET product from CSIRO performs best in this area. Zhao et al. [37] also found that MOD16 underestimates ET at $138.52 \mathrm{~mm} /$ year, especially in some arid areas with sparse vegetation. Wu et al. [29] compared five ET products derived from different methods in the Amazon River Basin during 1982-2011, and found that a machine-learning-derived ET product records the best performance at both site level and basin scale. Yin et al. [30] compared the accuracy of eight ET products (including MOD16, PML-V2 and BESS) in the Yellow River Basin and found that the Simplified Surface Energy Balance (SSEBop) model, after regional optimization, is most consistent with water balance evapotranspiration. MDO16 and SEBbased ET products were found to record a poor performance at the Murray-Darling Basin and in Northern China compared with global scales [37,38]. Therefore, the inconsistent performances of global actual ET products necessitate a comprehensive assessment before being applied at local or regional scales.

Eddy covariance observation has been recognized as an effective way to evaluate actual ET products $[4,29,36,39]$. It can directly observe latent heat and sensible heat simultaneously, which other measurements such as a scintillometer and Bowen ratio system cannot offer. Although site flux observations can provide direct validation, they cannot entirely be relied upon owing to the uncertainties brought by complex data processing algorithms, and the mismatch between footprint and estimated pixel values [39-41]. Thus, other supplementary validations or comparisons are necessary to fully evaluate the performances of global actual ET products $[42,43]$. Inter-comparison across climate zones is an important and indirect approach $[29,30]$, which can assess the spatial consistency among different ET products. Using ET observations from other regions with the same or similar climate zones is another potential approach to assessing the performance of ET products in areas with few or even no flux sites.

The Lancang-Mekong River (LMR) originates from the Tanggula Mountains in China and passes through Myanmar, Laos, Thailand, Cambodia and Vietnam. The river finally flows into the South China Sea from Ho Chi Minh City. As the largest transboundary river in Southeast Asia, LMR has attracted much attention from the world [44-46]. First of all, competition for water resources in this basin is obvious, especially for countries in its lower reaches. The rapid development of industry and agriculture in Southeast Asia has resulted in an increased demand for water resources. As a result, several dams have been built in the lower reaches of LMR as a step to better manage its water resources [47]. Characterized by diverse climate zones and complex vegetation types, it is challenging to accurately 
estimate the water budget in the LMR basin (LMRB). LMRB covers major climate types of the globe, including the equatorial climate zone, the warm temperate climate zone, snow and the polar climate zone from the south to the north. Meanwhile, the basin is rich in vegetation types, including tropical rainforests, tropical seasonal forests, subtropical forests, temperate deciduous forests, coniferous forests, savannas, alpine meadows, etc. Overall, the complexity and diversity of climate zones and land cover types makes this basin a representative study area for the evaluation of global ET products. Besides, although quite a lot of studies have explored the performances of global remote-sensing-derived ET products in different regions and basins, there is no such assessment for LMRB, despite its huge economic returns and ecosystem services. Hence, the objectives of this study are to: (1) evaluate the performances of four remote-sensing-derived ET products (i.e., MOD16, PML-V2, BESS and GLASS) based on Eddy Covariance (EC) observations, inter-comparison and comparisons with ET from literature in other regions with the same climate zones; and (2) analyze the potential reasons and uncertainties for the performance differences between the four products.

\section{Materials and Methods}

\subsection{Study Area}

Located in Southeast Asia, LMRB covers approximately $81.2 \times 10^{4} \mathrm{~km}^{2}$ (Figure 1) with a main stream length of $4880 \mathrm{~km}$, making it the fifth longest river in Asia. Landforms are diverse across the basin, including the Tibetan Plateau, the Yunnan-Guizhou Plateau, the Xiengkhouang Plateau, the Chuor Phnum Dangrek and the Mekong Delta region. The upper reach of LMRB is dominated by subtropical evergreen broadleaf forests, mountainous evergreen needle forests, alpine grassland, and alpine rocks and snow. The lower reach is dominated by tropical evergreen broadleaf forests, shrubs, wetlands and farmlands. With a population over 0.32 billion, LMRB provides a major source of water supply and is regarded as "the Golden Waterway" for the shipping industry in Southeast Asia. The annual mean ET is around $1000 \mathrm{~mm}$ /year over the basin. Figure 1 presents the elevation map, location of ET stations, and map of the major land cover types over LMRB.

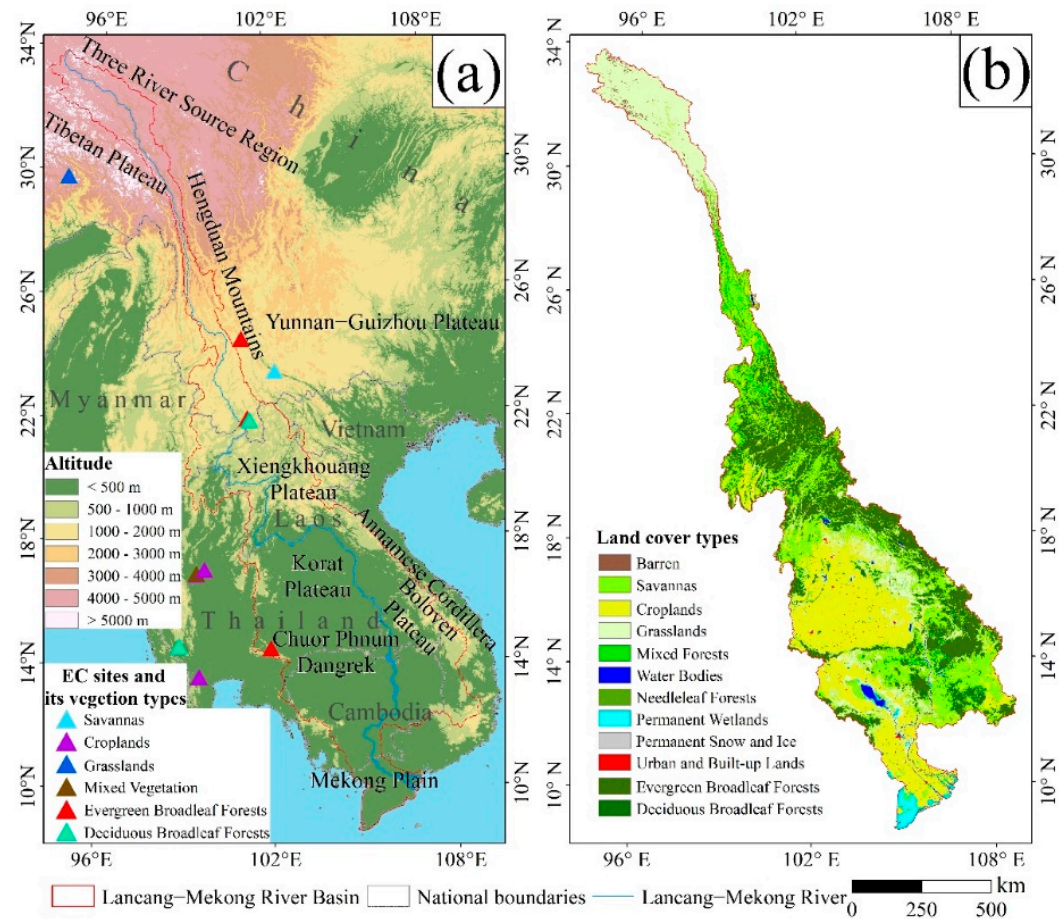

Figure 1. Basic geographic information of the Lancang-Mekong River Basin (LMRB): (a) elevation and distribution of EC sites; (b) land cover map from 2019. 


\subsection{Data}

\subsubsection{Land Cover Data}

The land cover data used in this study were derived from a Moderate-resolution Imaging Spectroradiometer (MODIS) land cover type product (MCD12Q1), which is also the source of input of land cover to the four remote sensing ET products [48]. The dataset is updated yearly with a spatial resolution of $500 \mathrm{~m}$. Land cover classification of MCD12Q1 was conducted using a supervised classification algorithm based on the International Geosphere-Biosphere Programme (IGBP) classification scheme, with 1860 training samples around the world. In order to better compare the ET values obtained in this study with those of previous studies, the IGBP classification scheme was modified to fit the major land cover types over LMRB (Table 1). The percentage area of each land cover type in 2019 is presented in Table 1.

Table 1. Land cover types and percentage coverage in LMRB in 2019.

\begin{tabular}{llc}
\hline Land Cover Used in This Study & \multicolumn{1}{c}{ IGBP Land Cover } & Area Ratio \\
\hline Evergreen Broadleaf Forests & Evergreen Broadleaf Forests & $24.83 \%$ \\
Deciduous Broadleaf Forests & Deciduous Broadleaf Forests & $1.63 \%$ \\
Needleleaf Forests & Evergreen Needleleaf Forests & $0.59 \%$ \\
Mixed Forests & Deciduous Needleleaf Forests & $0.00 \%$ \\
& Mixed Forests & $1.76 \%$ \\
Shrubs & Closed Shrublands & $0.01 \%$ \\
& Open Shrublands & $0.00 \%$ \\
Grasslands & Woody Savannas & $13.31 \%$ \\
Permanent Wetlands & Savannas & $12.54 \%$ \\
Croplands & Grasslands & $17.69 \%$ \\
Urban and Built-up Lands & Permanent Wetlands & $1.51 \%$ \\
Permanent Snow and Ice & Croplands & $22.49 \%$ \\
Barren Lands & Cropland/Natural Vegetation Mosaics & $1.90 \%$ \\
Water Bodies & Urban and Built-up Lands & $0.40 \%$ \\
\hline
\end{tabular}

\subsubsection{Remote Sensing Evapotranspiration Products}

Four high spatial resolution remote-sensing-derived ET products (MOD16, PML-V2, BESS and GLASS) were used in this study (Table 2). In order to make the spatial resolution of all products consistent, GLASS and BESS were downscaled to $500 \mathrm{~m}$ using the nearest neighbor resampling method [49]. Table 2 presents the characteristics of the remote sensing data and methods used in this study.

Table 2. Characteristics of the remote sensing data and methods used in this study.

\begin{tabular}{cccccc}
\hline Product & $\begin{array}{c}\text { Temporal } \\
\text { Resolution }\end{array}$ & $\begin{array}{c}\text { Estimation } \\
\text { Method }\end{array}$ & $\begin{array}{c}\text { Spatial } \\
\text { Resolution }\end{array}$ & Period & References \\
\hline MOD16 & 8-day/year & $\mathrm{PM}^{1}$ & $500 \mathrm{~m}$ & 2000 -Present & {$[11,26]$} \\
PML-V2 & 8-day/year & $\mathrm{PM}^{1}$ & $500 \mathrm{~m} / 0.01$ & $2000-2020$ & {$[7,9,25]$} \\
BESS & 8-day/month & $\mathrm{PM}^{1}$ & $1 \mathrm{~km}$ & $2001-2015$ & {$[27]$} \\
GLASS & 8-day & BMA $^{2}$ & $1 \mathrm{~km} / 0.01$ & $2000-2018$ & {$[28]$} \\
\hline
\end{tabular}

${ }^{1}$ PM: Penman-Monteith algorithm; ${ }^{2}$ BMA: Bayesian Multimodel Average algorithm.

\section{MOD16}

MOD16 calculates ET using a semi-empirical method based on the PM algorithm [11,26]. During the calculation, ET is divided into wet-canopy evaporation, vegetation transpiration and soil evaporation. The process of interception is actually not included in MOD16 directly as it is calculated only under wet canopy evaporation conditions. Compared with previous algorithms, the latest MOD16 algorithm improves the calculation of vegetation cover 
fraction, stomatal conductance, soil heat flux and night temperature [11]. In addition, during the calculation of soil evaporation, the soil surface is divided into wet and moist soil surfaces. However, MOD16 only considers the vegetation-covered area, and ignores barren or sparsely vegetated areas and non-vegetated areas.

\section{PML-V2}

PML-V2 was improved by Zhang et al. [7,9] on the basis of PML [25]. Unlike MOD16, PML-V2 also calculates canopy interception, besides soil evaporation and vegetation transpiration. In addition, PML-V2 couples the gross primary productivity (GPP) model to achieve the goal of carbon constraint on evapotranspiration [7]. The validation results of 95 flux stations around the world show that the RMSE of PML-V2 on a global scale is $0.73 \mathrm{~mm} /$ day. The accuracy of ET estimation has been improved in PML-V2 compared to PML and MOD16 [9]. Details of PML-V2 can be found in Zhang et al. (2019) [9].

\section{BESS}

BESS is a biophysical model that integrates an atmospheric radiative transfer model, a two-leaf canopy radiative transfer model and an integrated carbon assimilation-stomatal conductance-energy balance model [27]. Similar to PML-V2, BESS also couples carbon and water to better simulate the transfer of water vapor from the leaf to the atmosphere. In addition, BESS separately calculates carbon assimilation on sunlit and shaded leaves. Unlike PML-V2 and MOD16, which calculate the emissivity based on air temperature, BESS uses two constants of the emissivity of the leaf and the soil, which are 0.98 and 0.94 , respectively. In addition, BESS adopts a second-order Taylor equation to calculate the saturated vapor pressure, which could help to obtain an accurate latent heat compared with the traditional PM model in which it is estimated by the first-order linearization equation, especially when the temperature difference between air and leaves is higher than $5^{\circ} \mathrm{C}$ [50].

\section{GLASS}

GLASS is calculated by using the Bayesian averaging method to assign weight to 5 process-based algorithms [28], including the MOD16 ET algorithm [11], the revised PM algorithm [51], the PT-JPL algorithm [52], the revised PT algorithm [18] and the semiempirical PM algorithm [53]. Previous literature found the Bayesian algorithm to better improve the accuracy of ET estimation as it can obtain a good fitting weight for a set of station observations with the predictive probability density function [28]. Unlike the former three ET products, GLASS forces the energy balance closure using the Bowen ratio method.

\subsubsection{Eddy Covariance ET}

A total of 11 EC sites were obtained to evaluate the ET of each product over LMRB. As there are only three sites available within the basin, other sites were selected surrounding LMRB. These sites cover the major vegetation types over the basin. The detailed site and data information is provided in Table 3. In summary, there are three evergreen broadleaf sites, two deciduous broadleaf sites, three crop sites, a grass site, a shrub site and a mixed vegetation site. It is worth noting that ET data of four sites from FluxPro were from the literature, and only monthly data were available at these sites $[54,55]$. The quality of all the ET data was well controlled. In this study, only data acquired during the daytime were used. Daytime was defined as periods corresponding to shortwave radiation greater than $10 \mathrm{~W} / \mathrm{m}^{2}$. In order to match the temporal scale of ET products, EC observations were upscaled to 8-day and monthly time scales. Energy balance correction was conducted by using the Bowen ratio method [56]. Soil heat flux was not considered during the energy balance correction as it was negligible at 8-day and monthly scales $[9,25]$. 
Table 3. Characteristics of the flux sites used in this study.

\begin{tabular}{|c|c|c|c|c|c|c|}
\hline Site Name & Latitude $\left({ }^{\circ} \mathrm{N}\right)$ & $\begin{array}{c}\text { Longitude } \\
\left({ }^{\circ} \mathrm{E}\right)\end{array}$ & Elevation (m) & $\begin{array}{c}\text { Vegetation } \\
\text { Type }\end{array}$ & Time Span & Source \\
\hline Yuanjiang & 23.48 & 102.18 & 481 & Shrub & 2013.6-2015.12 & [57] \\
\hline SKR & 14.49 & 101.92 & 543 & $\mathrm{EBF}^{1}$ & $2002-2003$ & ASIAFlux \\
\hline XSBNRa & 21.96 & 101.21 & 750 & EBF & 2003-2016 & [58] \\
\hline Ailaoshan & 24.54 & 101.03 & 2505 & EBF & 2009-2013 & [59] \\
\hline MKL & 14.58 & 98.84 & 231 & $\mathrm{DBF}^{2}$ & $2003-2004$ & ASIAFlux \\
\hline XSBNRu & 21.91 & 101.27 & 580 & $\mathrm{DBF}$ & 2010.7-2012.12, 2016 & {$[60]$} \\
\hline prt007 & 13.59 & 99.51 & 99 & Cropland & 2011.8-2017.7 & FluxPro \\
\hline ctt007 & 16.90 & 99.43 & 129 & Cropland & $2012.1-2017.9$ & FluxPro \\
\hline pst007 & 17.06 & 99.70 & 59 & Cropland & 2004.7-2009.3 & FluxPro \\
\hline $\mathrm{dtt} 030$ & 16.94 & 99.43 & 117 & $\mathrm{MV}^{3}$ & $2003.2-2016.2$ & FluxPro \\
\hline QZ-SETORS & 29.77 & 94.74 & 3326 & Grassland & 2008.1-2016.12 & - \\
\hline
\end{tabular}

${ }^{1}$ EBF: evergreen broadleaf forests; ${ }^{2}$ DBF: deciduous broadleaf forests; ${ }^{3} \mathrm{MV}$ : mixed vegetation.

\subsection{Methods}

\subsubsection{Validation}

Root Mean Square Error (RMSE), Mean Absolute Error (MAE) and Mean Residual Error (MRE) were used to evaluate the accuracy of the four ET products.

$$
\begin{aligned}
\text { RMSE } & =\sqrt{\frac{\sum_{i=1}^{n}\left(X_{\text {model }, i}-X_{o b s, i}\right)^{2}}{n}} \\
\text { MAE } & =\frac{\sum_{i=1}^{n}\left|\left(X_{\text {model }, i}-X_{o b s, i}\right)\right|}{n} \\
\text { MRE } & =\frac{\sum_{i=1}^{n}\left(X_{\text {model }, i}-X_{o b s, i}\right)}{n}
\end{aligned}
$$

where $n$ represents the number of samples; $X_{o b s, i}$ represents the observed (EC) value; and $X_{\text {model }, i}$ represents remote sensing product value, which was calculated by the mean ET of four $500 \mathrm{~m} \times 500 \mathrm{~m}$ pixels nearest to the EC site.

To test whether the accuracy of the four ET products exhibits significant differences, multiple comparisons with significance tests, at a confidence level of $95 \%$, were conducted by using a two-way analysis of variance (ANOVA) test in SPSS Statistics 26.0 software (International Business Machines Corporation in Armonk, New York, USA). Homogeneity of variance tests were examined before the implementation of multiple comparisons. During the multiple comparisons, the Least Significant Difference (LSD) model was implemented if the homogeneity of variance was significant, while the Tamhane T2 model was implemented if the homogeneity of variance was not significant.

\subsubsection{Inter-Comparison of the Four ET Products}

The spatial distribution of the four ET products was compared across the four seasons; spring (March-May), summer (June-August), autumn (September-November) and winter (December-February of the next year). Pearson correlation was conducted spatially among the four products to examine their spatial consistency. The temporal trends of annual average ET of the four products were calculated using the linear regression method. Spearman's rank analysis was conducted before linear regression. If the correlation coefficient was not significant, then the corresponding linear trend was not reliable and was not conducted.

\subsubsection{Comparison with Studies from the Same Climates}

The ET observations from the same climate zones were collected and used to compare the ET in LMRB. These ET observations were collected from the literature by searching the keywords "evapotranspiration", "eddy covariance", and different vegetation function 
types in Web of Science. Köppen-Geiger Climate classification was applied in this study to classify the ET values from the literature for a better comparison with this studied basin. The main types of Köppen-Geiger Climate classification include equatorial, arid, warm temperate, snow and polar climates. In this study, a new climate scheme with three types was proposed to better compare ET values from the literature with ET values from four ET products over LMRB. In the new climate scheme, equatorial, and snow and polar climates were unchanged while, warm temperate and arid were merged into a new type, namely warm climate. During the process of literature searching, only study sites that had the same climate zone included in the new climate scheme were selected to make the comparison. Finally, 39 EC sites of multi-year average ET from the literature were obtained (Appendix A). Comparisons between literature-derived ET values and ET from the four products were conducted based on the same climate zone. Boxplots with mean, maximum statistics and minimum statistics were also used in the comparison.

\section{Results}

\subsection{Performance Assessment Based on Eddy Covariance}

Overall, the RMSEs of all four products are less than $8 \mathrm{~mm}$ and $31 \mathrm{~mm}$ at 8-day and monthly scales, respectively (Figure 2), implying that the RMSE of each product is approximately less than $1 \mathrm{~mm}$ per day. Residuals between predicted ET and observed ET of the four products indicates an overall overestimation of GLASS and an underestimation of the other three products. The accuracy of MOD16 is the lowest among the four ET products, with an 8-day RMSE of $0.47 \mathrm{~mm}, 0.90 \mathrm{~mm}$ and $0.66 \mathrm{~mm}$ higher than that of PML-V2, BESS and GLASS, respectively (Figure 2(a1,b1,c1,d1). Besides, its monthly RMSE is also higher than that of PML-V2, BESS and GLASS, at around $4.66 \mathrm{~mm}, 6.33 \mathrm{~mm}$ and $7.72 \mathrm{~mm}$ (Figure 2(a2,b2,c2,d2), respectively. The poor performance of MOD16 can be further proven by the boxplot of absolute error, in which it has much higher values of statistical indicators (i.e., mean value, maximum value and minimum value) than the other three products (Figure 3). The main source of the differences between MOD16 and the other three products comes from regions with low observed ET (i.e., $<20 \mathrm{~mm}$ at an 8 -day scale and $<80 \mathrm{~mm}$ at a monthly scale) where MOD16 has a much higher overestimation than PML-V2, GLASS and BESS. It is worth noting that the difference between MOD16 and GLASS is significant (at the level of $\alpha=0.05$ ) both at 8-day and monthly scales. Correspondingly, they have the largest MAE discrepancy of $0.93 \mathrm{~mm}$ and $6.72 \mathrm{~mm}$, respectively, among all the product comparisons. No significant difference is found among PML-V2, BESS and GLASS both at 8-day and monthly scales (Table 4) as the RMSE and MAE of PML-V2, BESS and GLASS are very close; correspondingly, they have the largest RMSE difference at less than $0.43 \mathrm{~mm}$ and $3.06 \mathrm{~mm}$, respectively. This can also be reflected by the boxplot of absolute error in which the statistical distributions of these three products are approximately close (Figure 2(a1,a2)). At an 8-day scale, GLASS has the lowest MAE of $0.66 \mathrm{~mm}$ per day, while BESS has the lowest RMSE of $0.87 \mathrm{~mm}$ per day. At a monthly scale, GLASS has both the lowest MAE $(17.18 \mathrm{~mm})$ and RMSE $(22.71 \mathrm{~mm})$. The monthly MAE $(19 \mathrm{~mm})$ and RMSE $(24.10 \mathrm{~mm})$ of BESS is slightly higher than that of GLASS, respectively. The good performance of BESS and GLASS indicates a slight advantage than the other products over LMRB. 

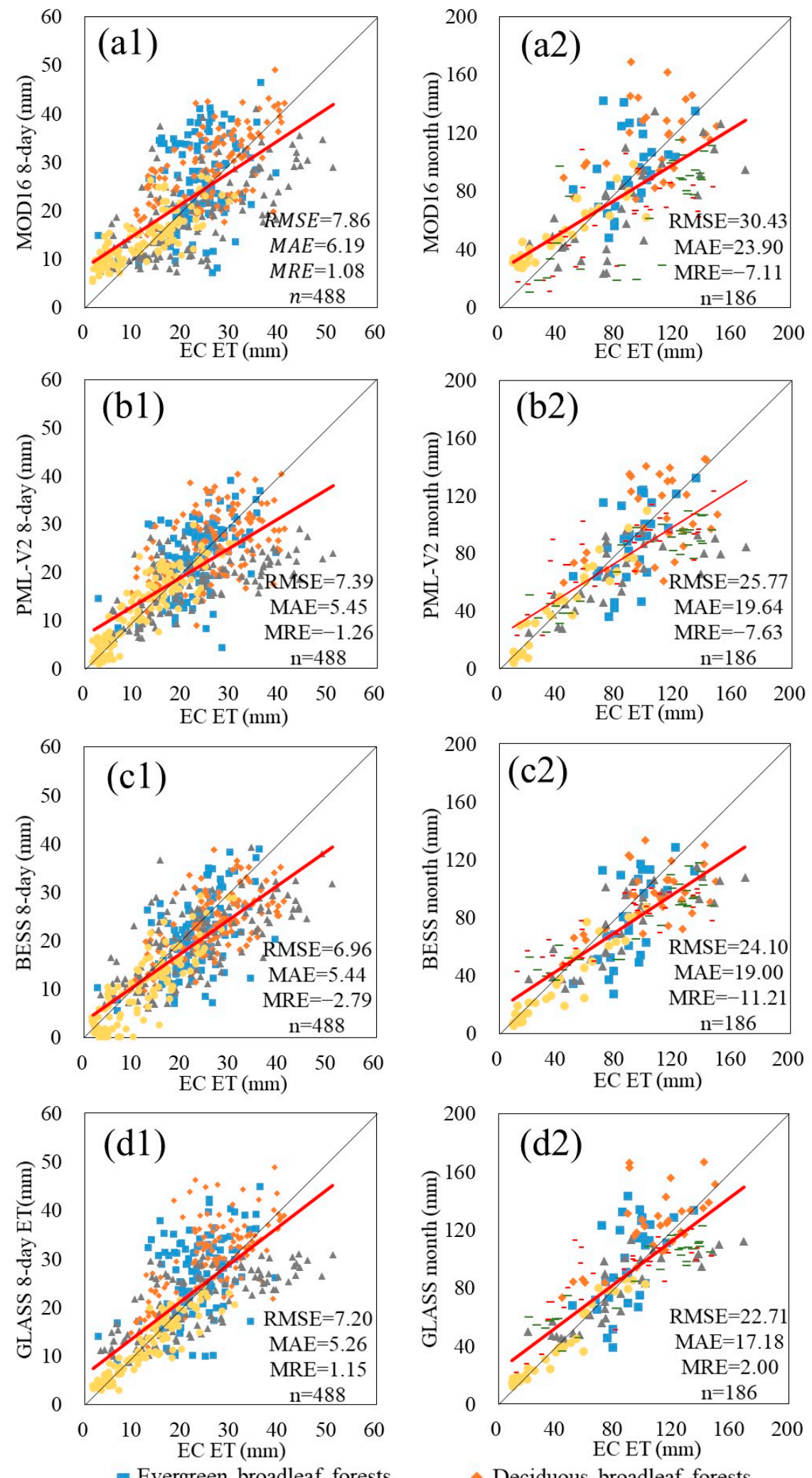

Evergreen broadleaf forests

- Deciduous broadleaf forests

^Savannas Grasslands

- Croplands - Mixed vegetation

Figure 2. Scatterplots of 8-day (a1, b1, c1 and d1 for MOD16, PML-V2, BESS and GLASS, respectively) and monthly (a2, b2, c2 and $\mathbf{d} 2$ for MOD16, PML-V2, BESS and GLASS, respectively) ET products against EC ET for all the assessing sites. 

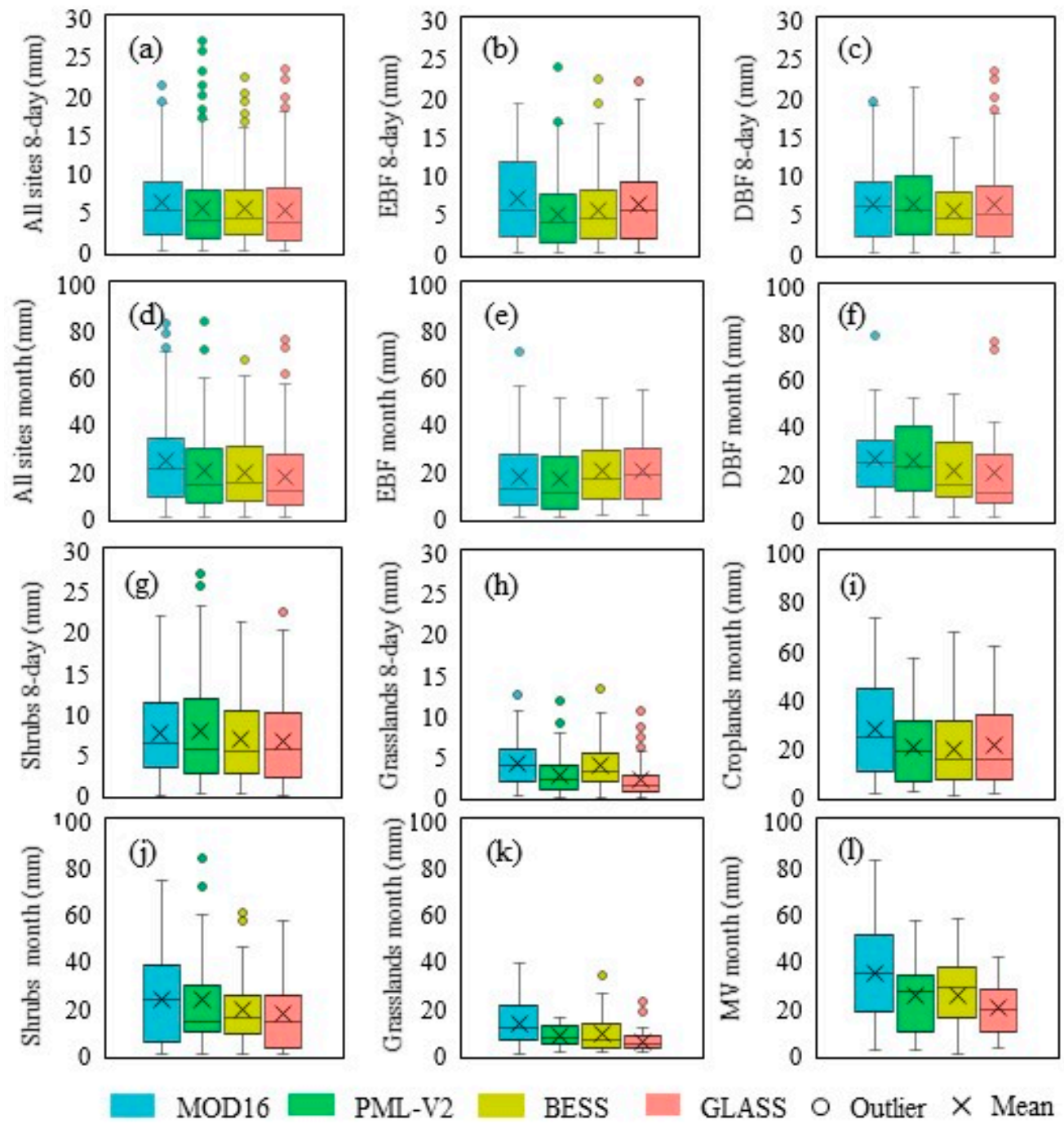

(k)

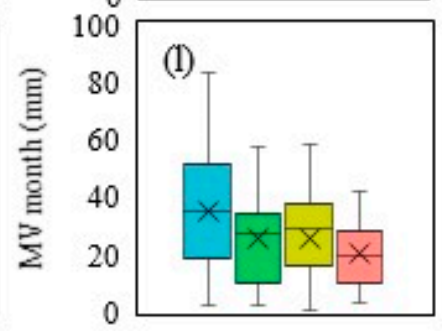

Figure 3. Boxplots of mean absolute error (MAE) for all four ET products and EC ET in 8-day (a-c,g,h) and monthly $(\mathbf{d}-\mathbf{f}, \mathbf{i}-\mathbf{l})$ scales.

Table 4. Multiple comparison test of the four ET products using the mean absolute error of all sites and various vegetation types.

\begin{tabular}{|c|c|c|c|c|c|c|c|}
\hline $\begin{array}{l}\text { Vegetation } \\
\text { Types }\end{array}$ & Time Scales & $\begin{array}{l}\text { MOD16 vs. } \\
\text { PML-V2 }\end{array}$ & $\begin{array}{l}\text { MOD16 vs. } \\
\text { GLASS }\end{array}$ & $\begin{array}{l}\text { MOD16 vs. } \\
\text { BESS }\end{array}$ & $\begin{array}{l}\text { PML-V2 vs. } \\
\text { GLASS }\end{array}$ & $\begin{array}{l}\text { PML-V2 vs. } \\
\text { BESS }\end{array}$ & $\begin{array}{l}\text { GLASS vs. } \\
\text { BESS }\end{array}$ \\
\hline \multirow{2}{*}{ All sites } & 8-day & 0.112 & 0.019 * & 0.064 & 0.993 & 1.000 & 0.993 \\
\hline & Monthly & 0.124 & $0.001 *$ & 0.034 * & 0.579 & 0.999 & 0.805 \\
\hline \multirow{2}{*}{$\mathrm{EBF}$} & 8-day & 0.018 * & 0.934 & 0.122 & 0.205 & 0.967 & 0.665 \\
\hline & Monthly & 0.726 & 0.553 & 0.574 & 0.346 & 0.362 & 0.975 \\
\hline \multirow{2}{*}{$\mathrm{DBF}$} & 8-day & 0.714 & 0.987 & 0.307 & 0.701 & 0.165 & 0.315 \\
\hline & Monthly & 0.788 & 0.141 & 0.243 & 0.228 & 0.367 & 0.760 \\
\hline \multirow{2}{*}{ Shrub } & 8-day & 1.000 & 0.534 & 0.939 & 0.446 & 0.862 & 0.988 \\
\hline & Monthly & 0.954 & 0.148 & 0.303 & 0.164 & 0.331 & 0.673 \\
\hline \multirow{2}{*}{ Grassland } & 8-day & $0 *$ & 0 * & 0.935 & 0.213 & $0.002 *$ & 0 * \\
\hline & Monthly & 0.031 * & 0.001 * & 0.348 & 0.407 & 0.958 & 0.239 \\
\hline Cropland & Monthly & 0.097 & 0.116 & 0.071 & 0.927 & 0.881 & 0.809 \\
\hline MV & Monthly & 0.207 & 0.004 * & 0.193 & 0.624 & 1.000 & 0.459 \\
\hline
\end{tabular}

${ }^{*}$ indicates a significant difference at $95 \%$ confidence. 
It is obvious that the performances at 8-day scales are highly consistent with performances at monthly scales in each land cover type for all the four products (Figure 3 and Table 5). This is also consistent with their performance when using all the land cover sites. ET performance comparison of the four products in different land cover types indicates that no product can perform best for all the land cover types (Table 5 and Figure 3). For evergreen broadleaf forests, PML-V2 performs best because it has both the lowest 8-day $(6.61 \mathrm{~mm})$ and monthly $(22.01 \mathrm{~mm})$ RMSE among the four products. For deciduous broadleaf forests, BESS performs best with its 8-day and monthly RMSE of 6.49 and 21.45 $\mathrm{mm}$, respectively. BESS also performs best for croplands as it has the lowest monthly RMSE of $22.35 \mathrm{~mm}$ among the four products. For shrubs, grasslands and mixed types, GLASS has consistently the lowest RMSE among the four products. Although GLASS, BESS and PML-V2 have their corresponding best performance with some land cover types, no significant MAE difference is found among the three products in all the land cover types except cropland, in which a significant MAE difference is found both between BESS and GLASS and between BESS and PML-V2 (Table 4). It is worth noting that MOD16 does not have the best performance in any land cover type as it records the highest RMSE in almost all land cover types, and significant MAE differences are mostly found between MOD16 and the other three products (Table 4).

Table 5. Evaluation results of ET products in diverse vegetation types.

\begin{tabular}{|c|c|c|c|c|c|c|c|c|c|}
\hline $\begin{array}{c}\text { Time } \\
\text { Scales }\end{array}$ & Products & Indicators & All Sites & EBF & DBF & Shrub & Grassland & Cropland & MV \\
\hline \multirow{8}{*}{ 8-day } & \multirow{2}{*}{ MOD16 } & RMSE & 7.86 & 7.62 & 7.80 & 9.26 & 4.93 & - & - \\
\hline & & MAE & 6.19 & 6.05 & 6.44 & 7.56 & 4.10 & - & - \\
\hline & \multirow{2}{*}{ PML-V2 } & RMSE & 7.39 & 6.61 & 7.53 & 10.09 & 3.54 & - & - \\
\hline & & MAE & 5.45 & 5.28 & 6.11 & 7.76 & 2.73 & - & - \\
\hline & \multirow{2}{*}{ BESS } & RMSE & 6.96 & 7.02 & 6.49 & 8.74 & 4.36 & - & - \\
\hline & & MAE & 5.44 & 5.85 & 5.59 & 6.94 & 3.70 & - & - \\
\hline & \multirow{2}{*}{ GLASS } & RMSE & 7.20 & 7.13 & 7.41 & 8.21 & 3.34 & - & - \\
\hline & & MAE & 5.26 & 5.58 & 5.79 & 6.52 & 2.39 & - & - \\
\hline \multirow{8}{*}{ Monthly } & \multirow{2}{*}{ MOD16 } & RMSE & 30.43 & 26.19 & 30.59 & 30.49 & 16.47 & 40.10 & 38.82 \\
\hline & & MAE & 23.90 & 20.74 & 25.49 & 23.78 & 13.36 & 31.97 & 31.00 \\
\hline & \multirow{2}{*}{ PML-V2 } & RMSE & 25.77 & 22.01 & 25.95 & 32.37 & 10.81 & 25.55 & 27.65 \\
\hline & & MAE & 19.64 & 17.48 & 21.71 & 23.51 & 8.63 & 19.92 & 21.47 \\
\hline & \multirow{2}{*}{ BESS } & RMSE & 24.10 & 23.70 & 21.45 & 24.34 & 12.77 & 22.35 & 28.77 \\
\hline & & MAE & 19.00 & 19.55 & 18.35 & 18.94 & 10.85 & 19.14 & 22.66 \\
\hline & \multirow{2}{*}{ GLASS } & RMSE & 22.71 & 24.46 & 25.13 & 22.64 & 10.45 & 27.65 & 22.58 \\
\hline & & MAE & 17.18 & 18.93 & 19.59 & 16.95 & 7.13 & 22.36 & 18.38 \\
\hline
\end{tabular}

\subsection{Performance Based on Inter-Comparison}

Overall, all four products do not show a uniform spatial pattern, although a consistently low ET in the north and high ET in the south can be observed (Figure 4). However, each product can well reflect the spatial differences brought by topography, climate and vegetation over the entire basin. Great spatial differences can be found in local regions. The multi-year average ET of GLASS is around 100 to $300 \mathrm{~mm}$ higher than that of the other three products in the Xiengkhouang Plateau and the Boloven Plateau, where evergreen broadleaf forest is the dominant land cover type. MOD16 presents the lowest multi-year average ET in the Korat Plateau, the Chuor Phnum Dangrek and the Mekong Delta Region, where the land cover is dominated by croplands. Spatial differences among the four products are more obvious in the seasonal average ET. In spring, MOD16 also presents the lowest average ET in the Korat Plateau, Chuor Phnum Dangrek and Mekong Delta Region. In the other three seasons, the largest spatial disagreement among the four products is distributed 
in the Xiengkhouang Plateau, Boloven Plateau and Mekong Delta region. For example, the summer ET of GLASS is around 100 to $200 \mathrm{~mm}$ higher than for the other three products in the Xiengkhouang Plateau and Boloven Plateau.
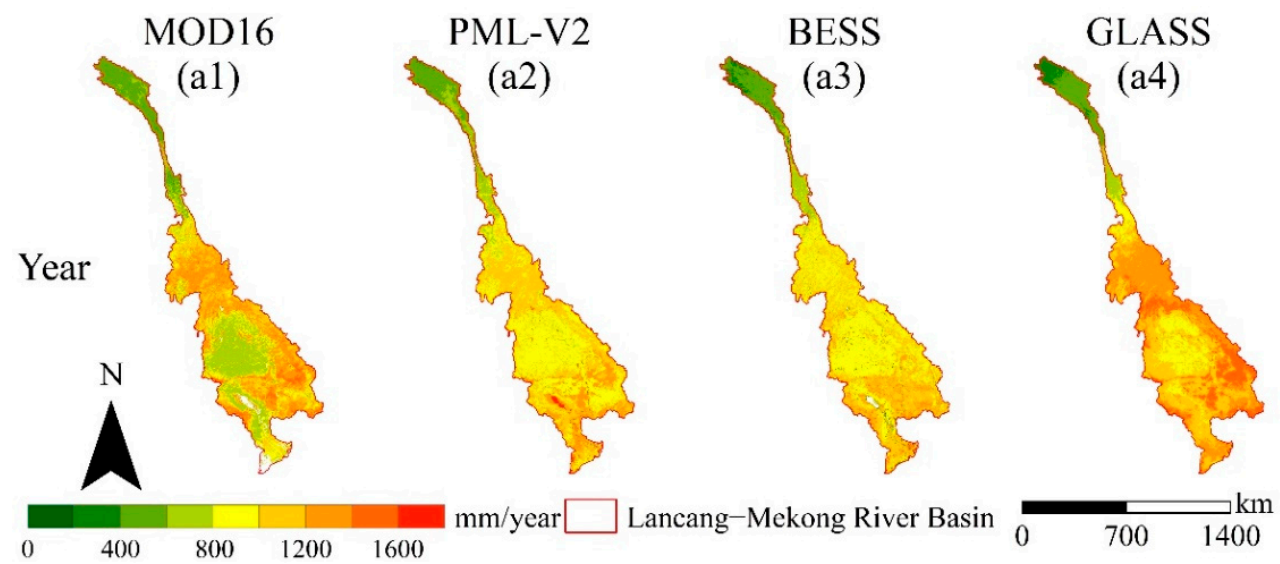

Figure 4. Spatial ET of multi-year average of the four products. (a1), (a2), (a3) and (a4) are multi-year average ET of MOD16, PML-V2, BESS and GLASS respectively.

The annual average ET ranges from 800 to $1400 \mathrm{~mm} /$ year across the basin, according to all four products (Figure 4(a1-a4)). The highest spatial agreement among the four products can be observed in the up reach, dominated by grasslands with an annual average ET range of 400 to $600 \mathrm{~mm}$ /year. The ET of all products in the Three River Source Region of the up reach is relatively low (around 100 to $200 \mathrm{~mm}$ ) as this region belongs to the snow and polar climate zone, with a mean altitude higher than $4000 \mathrm{~m}$. The spatial distribution of the ET of MOD16 and PML-V2 is well consistent in summer and winter (Figure 5), especially in the Xiengkhouang Plateau, Korat Plateau and Boloven Plateau.

The spatial correlation shown in Figure 6 further indicates a great spatial difference among the four products during 2001-2015. Spatial correlations between MOD16 and BESS, between PML-V2 and GLASS, and between GLASS and BESS show great spatial discrepancies. For example, high positive spatial correlations can be observed in the Korat Plateau, while negative correlations can be found in the Mekong Delta region between PML-V2 and GLASS. Conversely, negative spatial correlations can be observed in the Korat Plateau, while positive correlations can be found in the Mekong Delta region between MOD16 and BESS. A general negative spatial correlation between PML-V2 and BESS can be observed, especially in the upper reach, the Korat Plateau and the Chuor Phnum Dangrek.

Figure 7a shows comparisons of the annual ET of the four products over the entire basin in different land cover types. The four products show a comparable annual ET range of needleleaf forests, shrubs and grasslands with mean yearly ET of 717.2 mm (Figure 7(a3)), $1054.0 \mathrm{~mm}$ (Figure 7(a4)) and $698.9 \mathrm{~mm}$ (Figure 7(a6)), respectively. The annual ET range of MOD16 and PML-V2 is comparable in evergreen broadleaf forests with a mean yearly ET of around $1200 \mathrm{~mm}$, while those of BESS and GLASS are much lower and higher, with their mean yearly ET of $1019.0 \mathrm{~mm}$ and $1359.2 \mathrm{~mm}$, respectively (Figure 7(a1)). Specifically, BESS is $177.4 \mathrm{~mm}$ lower than the average of the four products, while GLASS is $162.8 \mathrm{~mm}$ higher than the average of the four products. In addition, the annual ET ranges of MOD16, BESS and GLASS are comparable in deciduous broadleaf forests with a mean yearly ET of around $1150 \mathrm{~mm}$, while that of PML-V2 is much lower (Figure 7(a2)). Specifically, PML-V2 is $175.78 \mathrm{~mm}$ lower than the average of the four products. A large discrepancy in the annual ET range between MOD16 and GLASS on croplands can also be found (Figure 7(a5)). The mean yearly ET of PML-V2 and GLASS on cropland are around $1040 \mathrm{~mm}$ and are comparable, though the annual ET range of the former is much broader than the latter (Figure 7(a5)). 


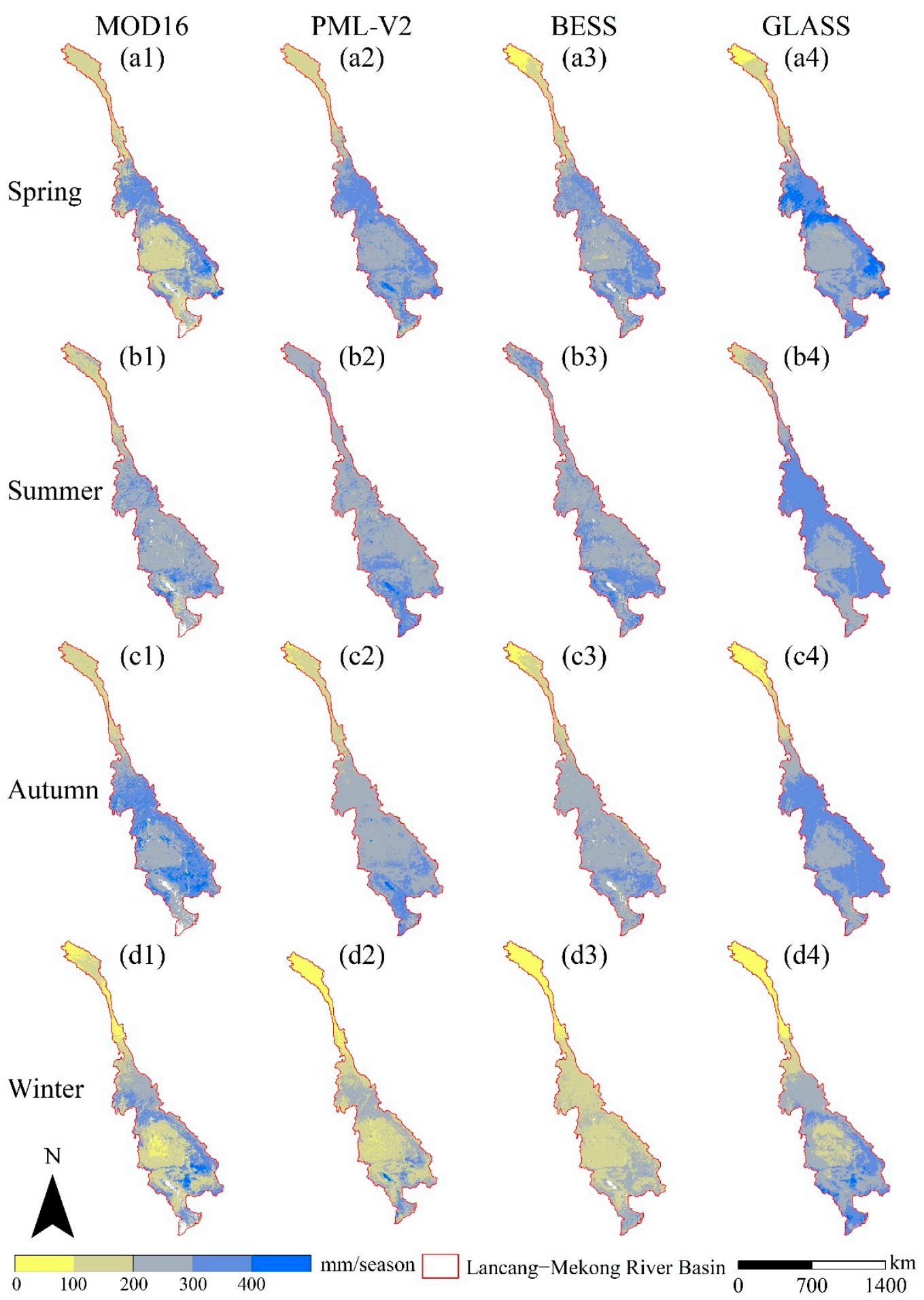

Figure 5. Spatial ET of multi-year seasonal average of the four products. (a), (b), (c) and (d) represent spring, summer, autumn and winter respectively, and 1, 2, 3, 4 represent MOD16, PML-V2, BESS and GLASS respectively. 
(a) MOD16 VS. PML-V2

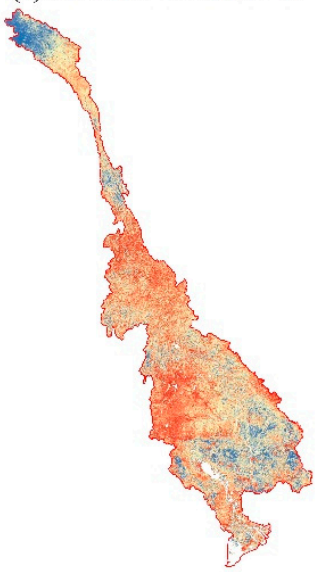

(d) PML-V2 VS. GLASS

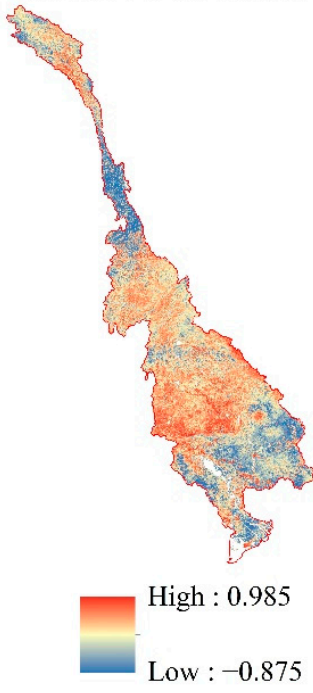

(b) MOD16 VS. GLASS

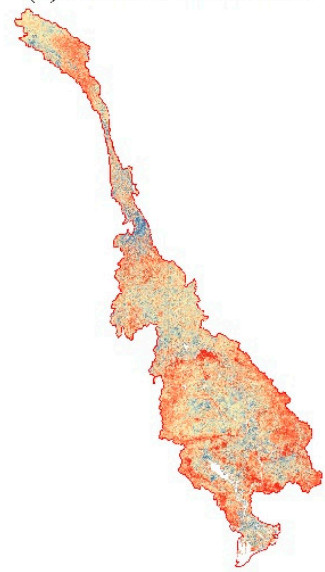

(e) PML-V2 VS. BESS

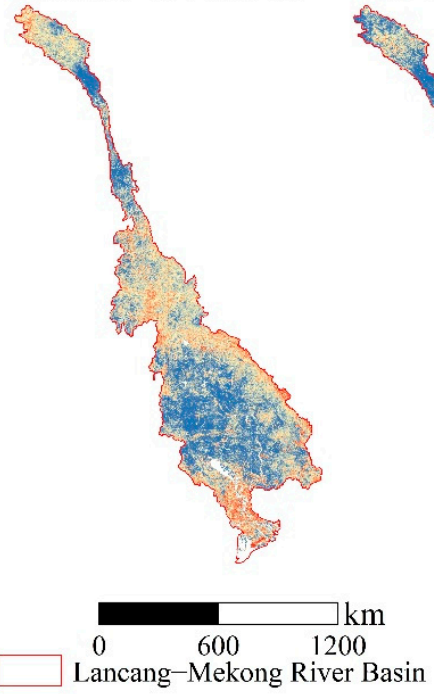

(c) MOD16 VS. BESS

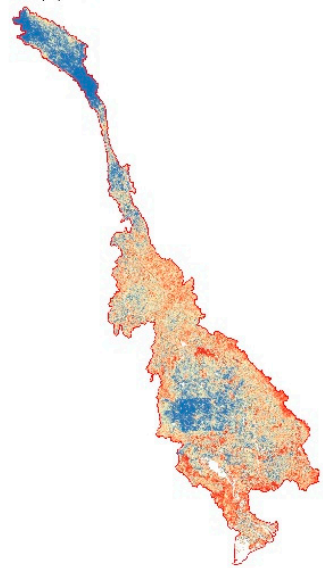

(f) GLASS VS. BESS

Figure 6. Spatial correlation of annual evapotranspiration between MODIS and PML-V2 (a), MOD16 and GLASS (b), MOD16 and BESS (c), PML-V2 and GLASS (d), PML-V2 and BESS (e), and between GLASS and BESS (f) over the entire basin.

The average yearly ET of the four products over the entire basin is around $1000 \mathrm{~mm}$ during the studied period (Figure $7 \mathrm{~b}$ ). The annual ET difference between MOD16, PMLV2 and BESS is relatively small, while the annual ET difference between GLASS and the other three products is significant. Specifically, the annual ET of the entire basin from GLASS fluctuates around $1100 \mathrm{~mm}$ during the period of 2001-2015, which is around 150 to $200 \mathrm{~mm}$ higher than that from the other three products (Figure 7b). The annual ET of the four products over the entire basin shows an increasing trend, with $3.8 \mathrm{~mm}$ per year (Figure 7b). Significant differences can be found in the trends of the annual ET of the four products. MOD16 and PML-V2 show significantly increasing trends (at a confidence level of $\alpha=0.1$ ), while BESS and GLASS do not show significant trends. PML-V2 increases by about $261.4 \mathrm{~mm}$ in 15 years (9.46 mm/year), and MOD16 increases by $83.69 \mathrm{~mm}$ (16.74 mm/year) during 2001-2015. It should be noted that the linear trends of BESS and GLASS are not presented in Figure 7b, as their Spearman's rank correlation coefficients are not significant; namely their linear trends are not reliable. 

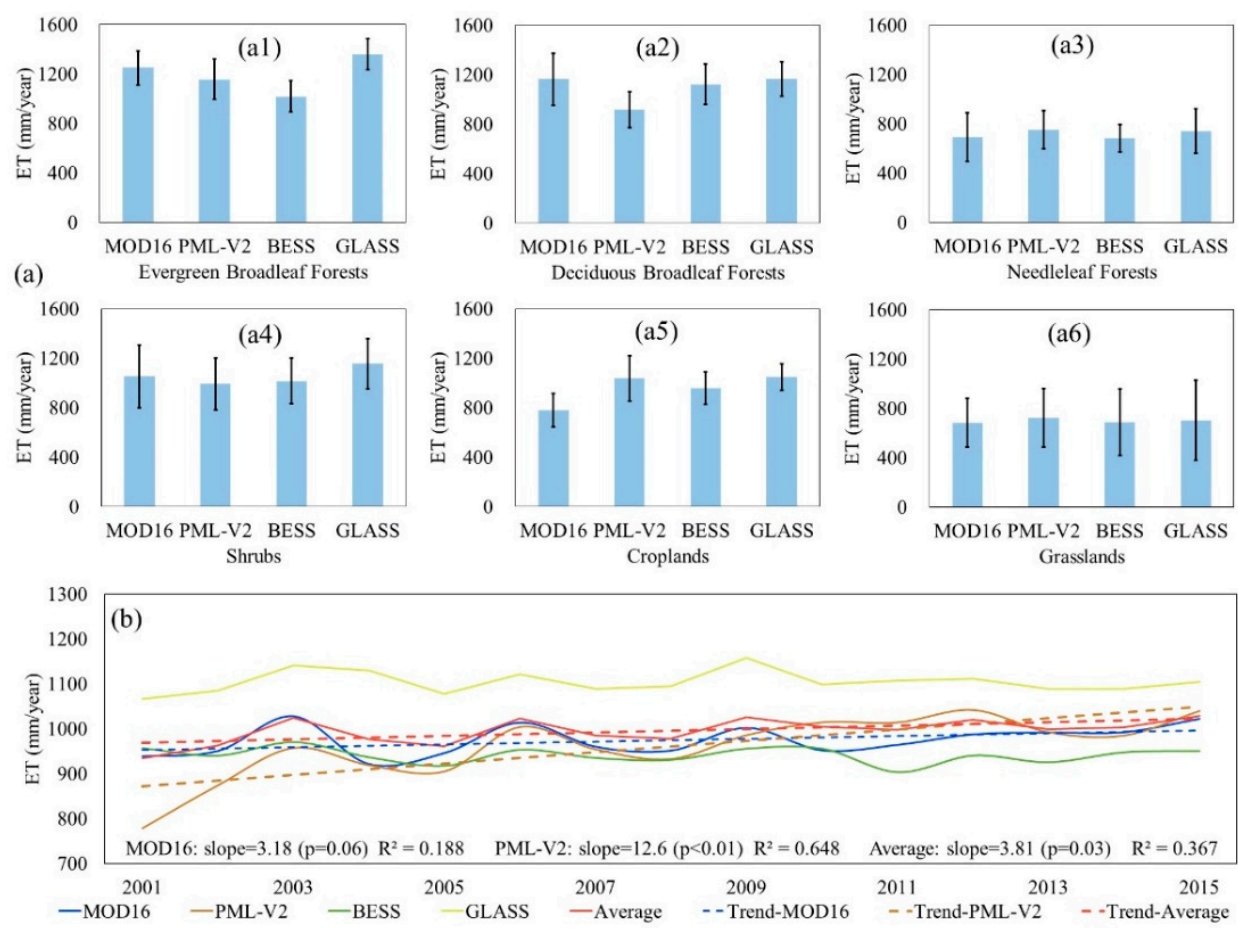

Figure 7. (a) Multi-year average ET of evergreen broadleaf forest (a1), deciduous broadleaf forests (a2), needleleaf forests (a3), shrubs (a4), croplands (a5), and grasslands (a6) over LMRB; (b) interannual variation of the four products and trend of MOD16, PML-V2, and the average ET during 2001-2015.

\subsection{Performance Based on Literature Comparison}

Figure 8 shows the results of the multi-year average ET comparison from different climate zones between the four products, and the ET values from the literature in other regions. In the equatorial climate zone, the multi-year average ET of evergreen broadleaf forests, with the four products, ranges from $1000 \mathrm{~mm}$ to $1400 \mathrm{~mm}$, with a mean value of $1226.90 \mathrm{~mm}$, which is comparable to the ET of the same climate from the literature (Figure 8a). However, the ET discrepancy between the products and the literature is larger in shrubs and croplands (Figure 8a). Specifically, the multi-year average ET (1127.23 mm) of the four products is much higher than that from the literature with a similar climate $(802.86 \mathrm{~mm})$ in shrubs, while it is much lower than that from the literature in croplands. This is reasonable, as croplands are more easily affected by human activities, and shrubs are more diverse in density compared to evergreen broadleaf forests. Thus, the multi-year average ET of evergreen broadleaf forests is more stable than that of shrubs and croplands in the same equatorial climate zone.

In the warm climate zone, the multi-year average ET of deciduous broadleaf forests $(721.16 \mathrm{~mm})$ and needleleaf forests $(751.09 \mathrm{~mm})$, with the four products, is also comparable to corresponding ET from the literature (Figure $8 b$ ). Similarly to the equatorial climate zone, the ET discrepancy between the products and the literature is also larger in croplands (Figure 8b). The multi-year average ET from the four products can be as much as $240.84 \mathrm{~mm}$ lower than ET from the literature over croplands. A great gap between ET from the products and ET from the literature can also be found in grasslands in the warm climate zone (Figure 8b). Specifically, the multi-year average ET from the products is around $290.76 \mathrm{~mm}$ higher than that from the literature in grasslands. The discrepancy between ET from the products and ET from the literature on croplands and grasslands in the warm climate zone may be explained by their disturbance differences due to human activities, such as irrigation and grazing in different regions. It is worth noting that the ET of croplands in the warm climate zone is lower than that in the equatorial climate zone regardless of the products and the literature. This ET difference is largely attributable to climate differences. 

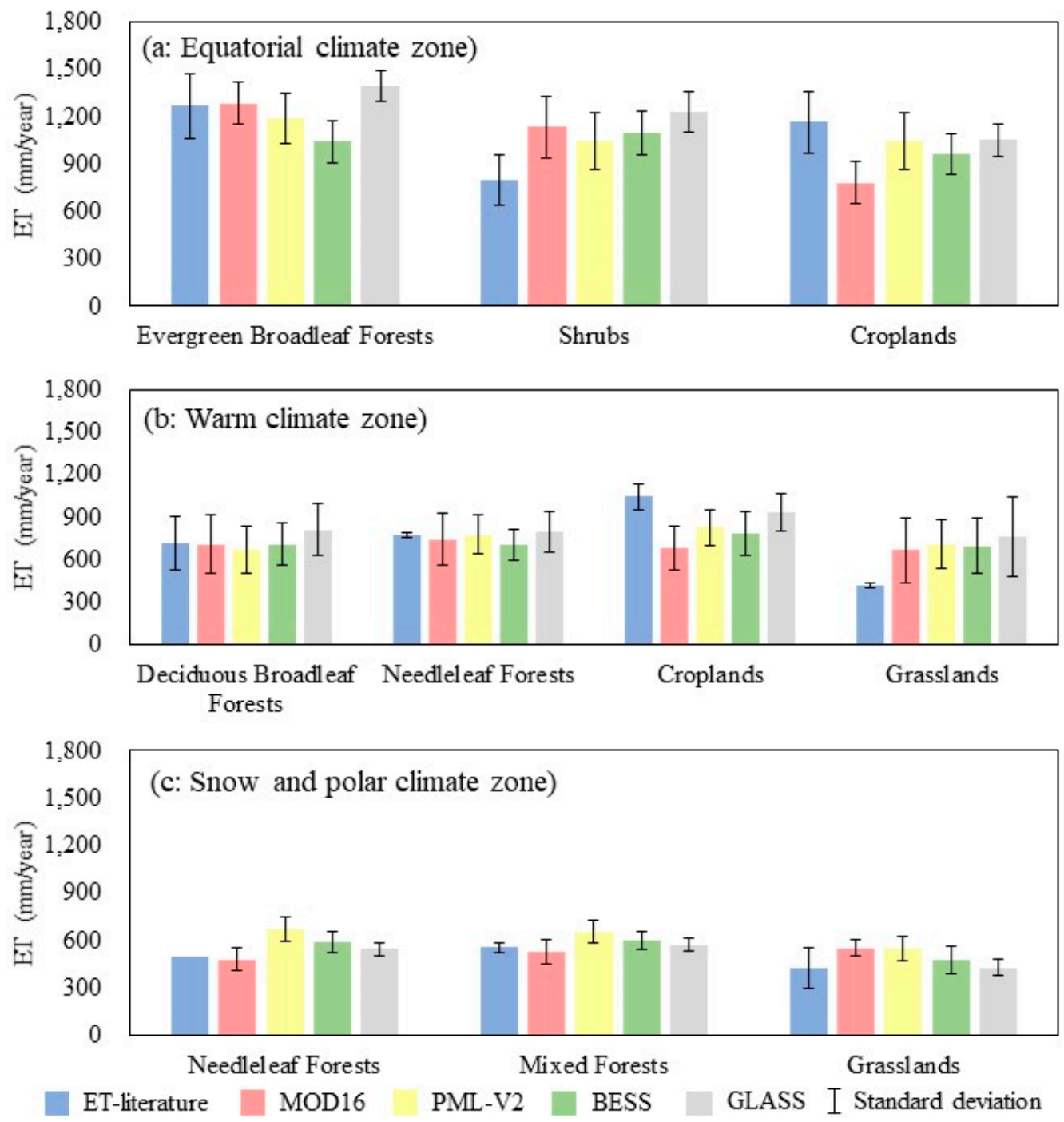

Figure 8. Comparison of multi-year average ET from equatorial climate zone (a), warm climate zone (b), and snow and polar climate zone (c) among the four products and ET values from literature in other regions.

In the snow and polar climate zone, ET from the products for all three land cover types (needleleaf forests, mixed forests and grasslands) is comparable to their corresponding ET from the literature (Figure 8c). This is because there is basically no human activity in this kind of cold climate region. The multi-year average ET of needleleaf forests is around $500 \mathrm{~mm}$ for all four products and the literature, which is comparable to that of mixed forest and grasslands in this region. It should be also noted that the annual average ET of needle leaf forests and grasslands in this cold climate region is much smaller than their corresponding annual average ET in the warm climate zone.

\section{Discussion}

\subsection{Possible Reasons for the Inconsistent Performance of the Four Products}

4.1.1. Inconsistency of Model Inputs

One main reason for the inconsistent performance of the four products could be the difference in the input datasets and their usage (Table 6). Firstly, the meteorological driving data for each ET product are different. For example, the meteorological driving data of MOD16, PML-V2 and BESS come from GMAO-MERRA, GLDAS and NCEP/NCAR, respectively. These three datasets have different temporal and spatial resolutions (Table 6). Previous studies suggested that GMAO-MERRA may overestimate the net radiation and 
shortwave radiation in the tropical climate region, while GLDAS may overestimate the net radiation and underestimate the incoming shortwave radiation [61]. The meteorological elements used in these three products are also different. MOD16 requires air temperature, atmosphere pressure, relatively humidity and downward shortwave radiation. BESS requires air temperature and wind speed. In addition to the same meteorological elements as required by MOD16, PML-V2 also requires precipitation, downward longwave radiation and wind speed.

Table 6. The major input datasets of MOD16, PML-V2, and BESS.

\begin{tabular}{|c|c|c|c|}
\hline Product Type & MOD16 & PML-V2 & BESS \\
\hline $\begin{array}{l}\text { Meteorological } \\
\text { Inputs }\end{array}$ & $\begin{array}{l}\text { GMAO-MERRA }\left(1^{\circ} \times 1.25^{\circ}\right) \\
\boldsymbol{T}_{\boldsymbol{a}}, \boldsymbol{P}_{a i r}, \mathbf{R H}, \boldsymbol{R}_{\boldsymbol{S}}\end{array}$ & $\begin{array}{l}\text { GLDAS_2.1 }\left(0.25^{\circ} \times 0.25^{\circ}\right) \\
\text { Prcp, } T_{a}, \boldsymbol{P}_{\text {air }}, \boldsymbol{R}_{S_{\downarrow}}, \boldsymbol{R}_{L \downarrow}, \text { WS }\end{array}$ & $\begin{array}{c}\mathrm{NCEP} / \mathrm{NCAR}\left(2.5^{\circ} \times 2.5^{\circ}\right) \\
\boldsymbol{T}_{\boldsymbol{a}}, \boldsymbol{T}_{\boldsymbol{d}}, \mathrm{LST}, \mathrm{WS}\end{array}$ \\
\hline LAI & MOD15A2 (1 km/8 day) & MCD15A3 (500 m/4 day) & MCD15A2 (1 km/8 day) \\
\hline FPAR & MOD15A2 (1 km/8 day) & - & - \\
\hline Albedo & $\begin{array}{c}\text { MOD43C1_collection5 } \\
\left(0.05^{\circ} / 16 \text { day }\right)\end{array}$ & MCD43A3 (500 m/8 day) & MCD43B3 (1 km/16 day) \\
\hline Albedo QC & - & - & MCD43B2 (1 km/16 day) \\
\hline Emissivity & - & MOD11A2 (500 m/8 day) & - \\
\hline $\begin{array}{l}\text { Sensing } \\
\text { Inputs }\end{array}$ & $\begin{array}{l}\text { MOD12Q1-UMD } \\
\text { (1 km/year })\end{array}$ & MCD12Q1-IGBP (500 m/year) & MCD12Q1-IGBP (500 m/year) \\
\hline LST & - & - & MO(Y)D11_L2 (1 km/5 min) \\
\hline Aerosol & - & - & $\mathrm{MO}(\mathrm{Y}) \mathrm{D} 04$ L2 (10 km/5 min) \\
\hline Water vapor & - & - & MO(Y)D05_L2 (5 km/5 min) \\
\hline Cloud & - & - & $\begin{array}{c}\mathrm{MO}(\mathrm{Y}) \mathrm{D} 06 \_L 2(1 \mathrm{~km} \text { or } \\
5 \mathrm{~km} / 5 \mathrm{~min})\end{array}$ \\
\hline $\begin{array}{l}\text { Atmospheric } \\
\text { Profile }\end{array}$ & - & - & MO(Y)D07_L2 (5 km/5 min) \\
\hline FCI & - & - & POLDER 3 (6 km/month) \\
\hline \multirow[t]{2}{*}{$\begin{array}{l}\text { Carbon dioxide } \\
\text { concentration }\end{array}$} & 1 & $\begin{array}{l}\text { NOAA-GAMSMMD } \\
\text { (global/year) }\end{array}$ & 370 ppm \\
\hline & \multicolumn{3}{|c|}{$\begin{array}{l}\text { LAI: Leaf Area Index; FPAR: the Fraction of Absorbed Photosynthetically Active Radiation; Albedo QC: } \\
\text { BRDF/albedo quality; LC: land cover; LST: land surface temperature; FCI: Foliar Clumping Index; } T_{a}: \text { air } \\
\text { temperature; NOAA-GAMSMMD: NOAA globally averaged marine surface monthly mean data; } T_{d p}: \text { dew point } \\
\text { temperature; } P_{a i r}: \text { air pressure; Prcp: precipitation; RH: relative humidity; } R_{S \downarrow}: \text { downward shortwave radiation; } \\
R_{L \downarrow} \text { : downward longwave radiation; WS: wind speed. }\end{array}$} \\
\hline
\end{tabular}

Secondly, the remote sensing input datasets of these ET products are inconsistent. Although all ET products use the same land cover product (MOD12Q1), only MOD16 integrates it into the ET algorithm. The biome property thresholds of leaf stomata, VPD and other related factors are set on the basis of land cover type in MOD16, while PML-V2 and BESS just used the land cover product to construct a mask of the terrestrial area. The sources and usage of LAI in these products are also different. LAI in both MOD16 and BESS comes from Terra, while PML-V2 comes from a combination of Terra and Aqua. Consequently, the spatial and temporal resolution of the three input LAI datasets are also different. For example, the spatiotemporal resolution of MCD15A3 (500 m/4 day) in PMLV2 LAI is better than that of MOD15A2 and MCD15A2 (1 km/8 day) in MOD16 and BESS. In addition, LAI is used to upscale the leaf conductance (including stoical, cultural and leaf boundary layer conductance) to canopy conductance in MOD16, while it is used to divide the total available energy into canopy absorption and soil absorption in PML-V2. Unlike MOD16 and PML-V2, LAI is used to estimate the downward longwave radiation and net radiation absorbed by the shaded and sunlit leaves in BESS. Additionally, the input albedo and emissivity datasets of each ET product are inconsistent. In terms of albedo, MCD43A3 is used in PML-V2, with a spatial resolution of $500 \mathrm{~m}$ and a temporal resolution of 8 days, while MOD43C1 $\left(0.05^{\circ} / 16\right.$ days) and MCD43B3 (1 km/16 days), with lower spatial and temporal resolution, are used in MOD16 and BESS, respectively. The higher spatiotemporal resolution of albedo in PML-V2 is most likely to obtain a more accurate radiation energy in 
simulating ET. Emissivity is used to calculate longwave radiation and net radiation. The algorithms of MOD16 and PML-V2 are same in calculating net radiation, but different in downward longwave radiation and upward longwave radiation. The downward longwave radiation of MOD16 is calculated by using the Stefan-Boltzman equation, which uses an empirical relationship to calculate atmospheric emissivity based on air temperature, while it directly comes from GLDAS in PML-V2 [62]. Similarly to MOD16, air emissivity is calculated by using a different empirical function related to air temperature in BESS [62,63]. In terms of upward longwave radiation, surface emissivity is set as a constant of 0.97 in MOD16, while it comes from MOD11A2 in PML-V2. Upward longwave radiation in BESS is calculated using constants of leaf and soil surface emissivity (i.e., 0.98 and 0.94, respectively) and land surface temperature from MOD11 L2 and MYD11 L2. Furthermore, compared with other products, BESS also requires other remote sensing datasets, including clouds, water vapor, aerosols, etc. These datasets are used in the Atmospheric Radiative Transfer Model to obtain downward shortwave radiation. It is worth noting that BESS also uses foliage clumping index rather than LAI to separate the proportion of shade and sunlit leaves.

Thirdly, carbon dioxide fertilization is considered in PML-V2, while it is not considered in both MOD16 and BESS. Carbon-dioxide concentration in BESS is set as a constant of 370 ppm, while carbon-dioxide concentration in PML-V2 is derived from the NOAA globally averaged marine surface monthly mean data. We suggest that PML-V2 is more reasonable with regards to this aspect, as carbon dioxide fertilization was proved to increase ET, which is coupled with net primary production $[7,64,65]$.

\subsubsection{Inconsistency of Model Structures}

The second reason for the inconsistent performance of these products comes from differences in model structures and algorithms. Firstly, BESS does not include evaporation from canopy interception, while both MOD16 and PML-V2 do. Canopy interception is an important part in ET besides canopy transpiration and soil evaporation. Previous studies showed that canopy interception could account for as much as 30\% of total precipitation in tropical forests [66]. Thus, the omission of canopy interception could bring a large error in tropical forests. It is worth noting that MOD16 does not fully consider evaporation from canopy interception, as it is set to 0 if relative humidity is less than $70 \%$.

Secondly, both PML-V2 and BESS couple with photosynthesis to constrain canopy surface resistance in the PM equation, while MOD16 does not. A missing carbon and water coupling process can bring large errors in estimating ET, especially when vegetation is subject to environmental stress (e.g., drought, heatwave, cold, etc.) [67]. Although both PML-V2 and BESS have considered the process of carbon and water coupling, their idea for calculating leaf photosynthesis is different. PML-V2 adopts the "big-leaf model" while BESS adopts the "two-leaf model" in which leaves are divided into shaded and sunlit leaves. In addition, BESS induces a clumping index, rather than LAI, to distinguish the structure of the canopy.

Thirdly, the method of calculating canopy surface resistance is different in MOD16, PML-V2, and BESS. Both PML-V2 and BESS apply the Ball-Woodrow-Berry equation [68] to calculate stomatal conductance, while MOD16 applies an empirical equation constrained by air temperature and atmosphere pressure. It should also be noted that PML-V2 uses relative humidity to constrain stomatal conductance in the Ball-Woodrow-Berry equation, while BESS uses vapor pressure deficit.

Fourthly, MOD16 considers ET in the night while both PML-V2 and BESS do not. Previous study suggested that leaf stomata are closed in the night and, thus, the leaf does not have a transpiration process in the night [11]. However, recently, more and more research has supported the existence of stomata opening in the night for some plants [69-71]. Thus, MOD16 seems be more reasonable in this aspect. 
It should be noted that we are unable to compare the input data and model structure differences between GLASS and the other three products, as it is produced by fusing several products instead of having independent model input and algorithms.

\subsection{Uncertainties in Assessment Method}

EC is widely used to evaluate actual ET around the world. However, final flux data from EC may be not consistent with the actual condition at times. This gap may result from instrument sensitivity, weather conditions, and gap filling methods. Eddy covariance instruments generally have two types of analyzers: open-path $\mathrm{CO}_{2} / \mathrm{H}_{2} \mathrm{O}$ analyzers, and closed-path $\mathrm{CO}_{2} / \mathrm{H}_{2} \mathrm{O}$ analyzers. However, gaps exist in the observed data of the two analyzers, due to their different working mechanisms for calculating vapor and gas flux. Different types of EC instruments were installed at the flux sites in this study. For example, closed-path $\mathrm{CO}_{2} / \mathrm{H}_{2} \mathrm{O}$ analyzers (LI-6262, LI-COR) were installed in SKR and MKL, while open-path $\mathrm{CO}_{2} / \mathrm{H}_{2} \mathrm{O}$ analyzers (LI-7500) were installed in XSBNRa and QZ-SETORS. This may lead to uncertainties the assessment result. Unfavorable weather conditions such as snow, rain fall, and hurricanes can influence the stability of instruments and lead to wrong records. The advective condition should also be paid more attention, as it can destroy the energy balance by introducing extra energy [72,73]. Wind speed has an influence on the source area of EC observation, and then brings errors for EC observation [74]. Different filling methods of EC gap data could also lead to discrepancy from actual ET [75]. Mean diurnal variation (MDV), look-up tables (LookUp), nonlinear regressions (Regr.) and artificial neural networks (ANN) are commonly used to gap-fill EC data $[14,76,77]$. However, previous studies have found that these methods can lead to quite large inconsistencies [75,77]. Falge et al. (2001) also suggested the need to standardize gap-filling methods to improve the comparability of flux data products, after comparison of seven gap-filling methods [75].

All of the sources of uncertainty further lead to a fundamental problem with EC; that is, the energy balances determined using EC are generally "unclosed", with the summary of sensible and latent heat fluxes often underestimating available energy by $20 \%$ or more [78]. Previous studies have shown that the energy balance closure ratio of forest stations in ChinaFLUX and ASIAFLUX is around 70-90\% [79]. Thus, quite a lot of researchers have suggested that the closure issue of measured energy fluxes must be resolved before it is used to evaluate energy and water exchange products $[73,78,80]$. Currently, two main methods are commonly used to "correct" energy imbalance. The first is called the residual method, which assumes that sensible heat is correct, and that the residual from the subtraction of available energy from the summary of sensible heat and latent heat can be taken as the underestimation of latent heat [78]. The second is called the Bowen ratio method, which assumes that the EC technique provides correct estimates of the Bowen ratio (the ratio of sensible heat to latent heat), thus the residual can be proportionally assigned to original sensible heat and latent heat [81-83]. However, there is no consistent answer on which method is better to close the energy budget to date. Additionally, inconsistency in calculating the available energy can be also found in previous studies $[9,32,34]$. The main question is, under what conditions can soil heat flux and heat storage in vegetation be neglected in calculating the available energy? Some studies have found that latent heat underestimation results from neglecting soil heat, and that canopy heat storage could be rather large $[84,85]$.

An additional three points should be noted in terms of the uncertainties of product assessment using EC data. The first is the well-known scale mismatch problem. The footprints of EC water vapor exchange are often not well matched with corresponding remote sensing ET pixels. Thus, the site-to-pixel assessment method used in most studies may not be reasonable. In this study, we used a grid with a window size of $2 \times 2$ instead of just one pixel to match the flux site. This may be more reasonable, especially if the grid is homogenous. The second is the mixture problem. In this study, the finest spatial resolution of ET products is $500 \mathrm{~m}$. This means it is unable to avoid mixed land cover types in such a coarse pixel. The evaluation result can be largely affected if selected flux sites cannot well 
represent the underlying land cover types in their corresponding remote sensing ET pixels. The last point is the representative problem. The selected flux site may be able to represent the actual water vapor exchange in its corresponding grid, but it may be not able to present all of the pixels with same land cover inside the study region. Thus, the assessment result would be more robust if more flux sites were available for the product evaluation. However, a problem facing all regions of the world is that existing flux sites are currently extremely limited. This study further conducts a comparison of flux data from other regions with the same climate zone, which could be an alternative solution to evaluating ET products. However, it should be noted that the area of the climate zones varies from year to year, and the time period chosen affects the results.

\subsection{Future Directions}

One possible future direction is to improve the accuracy of input datasets in calculating ET. The calculation of ET requires several variables, such as meteorological elements, land cover types, leaf area index, and land surface albedo, etc. Currently, these input datasets have different temporal and spatial resolutions at global and regional scale. Besides, current accuracies of some input datasets (e.g., precipitation, leaf area index) can hardly meet the demand of a highly accurate ET product. More research is needed to produce more accurate input datasets by improving their consistency in temporal and spatial resolutions and their algorithms. The second possible future direction is to fuse existing ET products. As shown in this study, most ET products perform best with a particular land cover type. The accuracy of the newly fused products would most likely be improved if a good fusion method were to be implemented or developed. A Generalized Three-Cornered Hat (GTCH) model may be a good candidate, as it can evaluate the uncertainty of more than three different datasets without an observation value [86]. Thirdly, more research is needed to improve the existing ET algorithms. Water balance in the soil-plant-atmosphere continuum is needed to be considered a priority. This is because water absorption from the soil layer and water storage change in the plant could greatly influence the escape of water from the leaf stomata [87]. The nitrogen cycle may be considered in the ET algorithm besides carbon and water, as coupling nitrogen deposition is found to improve the rate of photosynthesis [88]. When more carbon-dioxide is assimilated due to increased nitrogen supply, more water needs to transpire out from the stomata. Last, but not least, autocorrelation of series data should be conducted before conducting a linear trend, to evaluate its independence. If serial correlation is present in the time series data, it can considerably impact the outcome of trend analysis. Positive autocorrelation can artificially induce a trend in a time series, while negative autocorrelation can weaken the trend [89].

\section{Conclusions}

In this study, four high spatial resolution ET products (MOD16, PML-V2, BESS, and GLASS) were assessed and compared over LMRB, based on eddy covariance evaluation, spatiotemporal inter-comparison, and literature comparison. Results obtained reveal that MOD16 does not perform well as compared to the other three ET products. No significant differences are found among the other three products. The performance of each product varies across the different vegetation types, even within the same climate zone. In addition, the four ET products show neither a consistent temporal trend nor a uniform spatial distribution. The inconsistent performance of the four ET products over LMRB may be due to various reasons, including model inputs, model algorithms and assessment methods. In order to achieve more precise management of water resources, it is necessary to provide input data with high temporal and spatial consistency, and to optimize the estimation algorithm to improve the accuracy of ET products over LMRB.

Author Contributions: Conceptualization, H.C. and Y.C.; data curation, H.C., P.G., A.S. and G.F.; formal analysis, H.C., P.G., L.R.M. and Y.C.; funding acquisition, Y.C.; investigation, H.C.; methodology, Y.C.; project administration, Q.S. and Y.C.; resources, P.G., Q.S. and C.S.; software, H.C.; supervision, Q.S. and Y.C.; validation, H.C., A.S. and G.F.; visualization, P.G. and K.L.; writing-original draft, 
H.C. and L.R.M.; writing-review \& editing, P.G., L.R.M., Y.C. and K.L. All authors have read and agreed to the published version of the manuscript.

Funding: This research was funded by the National Natural Science Foundation of China, grant number 41901124.

Data Availability Statement: The eddy covariance data used in this study come from different sources. The EC dataset of two sites (SKR and MKL) was obtained from the ASIAFlux (http: / / asiaflux. net/ (accessed on 18 May 2021)). The EC dataset of four sites (prt007, ctt007, pst007 and dtt030) was obtained from FluxPro (http:/ / www.naro.affrc.go.jp/org/niaes/amen/ (accessed on 16 June 2021)). The EC dataset of four sites (Yuanjiang, XSBNRa, Ailaoshan, and XSBNRu) was obtained from http:/ / csdata.org/ (accessed on 10 June 2021). Notably, the EC dataset of QZ-SETORS is not available to the public. The four ET products were also downloaded from different websites. MOD16 was downloaded from https://modis.gsfc.nasa.gov/data/dataprod/mod16.php (accessed on 26 October 2020); PML-V2 was downloaded from https:/ / developers.google.com/earth-engine/ (accessed on 10 December 2020); GLASS was downloaded from http:/ / www.geodata.cn/ (accessed on 23 March 2021); BESS was downloaded from http:/ / environment.snu.ac.kr/ (accessed on 16 December 2020). The land cover product was downloaded from https:/ / lpdaac.usgs.gov/products/mcd12q1v006/ (accessed on 26 October 2020).

Acknowledgments: Thank you for the comments of the three anonymous review experts and editors.

Conflicts of Interest: The authors declare no conflict of interest.

\section{Appendix A}

Table A1. Information of 39 EC sites collected from literature.

\begin{tabular}{|c|c|c|c|c|c|c|c|}
\hline Code & Country & $\begin{array}{c}\text { Vegetation } \\
\text { Type }\end{array}$ & Locations & $\begin{array}{c}\text { ET } \\
(\mathrm{mm} / \text { Year })\end{array}$ & Period & $\begin{array}{l}\text { Köppen } \\
\text { Climate }^{1}\end{array}$ & $\begin{array}{c}\text { Modified } \\
\text { Climate Zone } \\
\text { Used in This } \\
\text { Study }\end{array}$ \\
\hline 1 & Cambodia & EBF & $12^{\circ} 44^{\prime} \mathrm{N}, 105^{\circ} 28^{\prime} \mathrm{E}$ & 1140 & $2003-2004$ & Aw & Equatorial \\
\hline 2 & Malaysia & $\mathrm{EBF}$ & $4^{\circ} 12^{\prime} \mathrm{N}, 114^{\circ} 02^{\prime} \mathrm{E}$ & 1545 & 2001-2002 & Af & Equatorial \\
\hline 3 & Malaysia & EBF & $2^{\circ} 58^{\prime} \mathrm{N}, 102^{\circ} 18^{\prime} \mathrm{E}$ & 1287 & 2003-2010 & Af & Equatorial \\
\hline 4 & Cambodia & EBF & $12^{\circ} 44^{\prime} \mathrm{N}, 105^{\circ} 28^{\prime} \mathrm{E}$ & 1140 & 2004 & Aw & Equatorial \\
\hline 5 & Thailand & EBF & $18^{\circ} 25^{\prime} \mathrm{N}, 99^{\circ} 43^{\prime} \mathrm{E}$ & 977 & 2007-2009 & Aw & Equatorial \\
\hline 6 & Vietnam & EBF & $11^{\circ} 27^{\prime} \mathrm{N}, 107^{\circ} 24^{\prime} \mathrm{E}$ & 1519 & 2011-2017 & Aw & Equatorial \\
\hline 7 & China & $\mathrm{DBF}$ & $41^{\circ} 59^{\prime} \mathrm{N}, 101^{\circ} 07^{\prime} \mathrm{E}$ & 653.4 & 2014 & BWk & Warm \\
\hline 8 & China & DBF & $29^{\circ} 31^{\prime} \mathrm{N}, 112^{\circ} 55^{\prime} \mathrm{E}$ & 1033 & 2010-2012 & Cfa & Warm \\
\hline 9 & China & DBF & $35^{\circ} 01^{\prime} \mathrm{N}, 112^{\circ} 28^{\prime} \mathrm{E}$ & 579 & 2006-2010 & Cwa & Warm \\
\hline 10 & China & DBF & $39^{\circ} 32^{\prime} \mathrm{N}, 116^{\circ} 16^{\prime} \mathrm{E}$ & 571 & 2006-2009 & Cwa & Warm \\
\hline 11 & Indonesia & Cropland & $1^{\circ} 08^{\prime} \mathrm{S}, 102^{\circ} 50^{\prime} \mathrm{E}$ & 1058 & 2001-2003 & Af & Equatorial \\
\hline 12 & Brazil & Cropland & $29^{\circ} 45^{\prime} \mathrm{S}, 53^{\circ} 9^{\prime} \mathrm{W}$ & 998 & 2003-2004 & Cfa & Warm \\
\hline 13 & Bangladesh & Cropland & $24^{\circ} 44^{\prime} \mathrm{N}, 90^{\circ} 25^{\prime} \mathrm{E}$ & 997 & 2007 & $\mathrm{Am}$ & Equatorial \\
\hline 14 & China & Cropland & $28^{\circ} 26^{\prime} \mathrm{N}, 116^{\circ} 00^{\prime} \mathrm{E}$ & 1174 & 2016-2017 & Cfa & Warm \\
\hline 15 & Philippines & Cropland & $14^{\circ} 8^{\prime} \mathrm{N}, 121^{\circ} 16^{\prime} \mathrm{E}$ & 1441 & 2008-2009 & Af & Equatorial \\
\hline 16 & Japan & Cropland & $36^{\circ} 03^{\prime} \mathrm{N}, 140^{\circ} 01^{\prime} \mathrm{E}$ & 956 & 2005 & $\mathrm{Cfa}$ & Warm \\
\hline 17 & Brazil & Shrub & $15^{\circ} 56^{\prime} \mathrm{S}, 47^{\circ} 53^{\prime} \mathrm{W}$ & 1060 & 2001-2003 & Aw & Equatorial \\
\hline 18 & Australia & Shrub & $12^{\circ} 30^{\prime} \mathrm{S}, 130^{\circ} 45^{\prime} \mathrm{E}$ & 958 & 1996-1998 & Aw & Equatorial \\
\hline 19 & Venezuela & Shrub & -2 & 732 & $2000-2001$ & Aw & Equatorial \\
\hline 20 & Venezuela & Shrub & -2 & 771 & 2000-2001 & Aw & Equatorial \\
\hline 21 & Brazil & Shrub & $15^{\circ} 56^{\prime} \mathrm{S}, 47^{\circ} 57^{\prime} \mathrm{W}$ & 840 & $2001-2002$ & Aw & Equatorial \\
\hline 22 & Venezuela & Shrub & -2 & 538 & 1999-2000 & Aw & Equatorial \\
\hline 23 & Venezuela & Shrub & -2 & 721 & 1999-2000 & Aw & Equatorial \\
\hline 24 & Mongolia & Grassland & $47^{\circ} 45^{\prime} \mathrm{N}, 107^{\circ} 20^{\prime} \mathrm{E}$ & 176.95 & 2003-2004 & Dwc & Snow and polar \\
\hline 25 & China & Grassland & $33^{\circ} 53^{\prime} \mathrm{N}, 102^{\circ} 08^{\prime} \mathrm{E}$ & 580 & 2010 & Dwb & Snow and polar \\
\hline 26 & China & Grassland & $27^{\circ} 10^{\prime} \mathrm{N}, 100^{\circ} 14^{\prime} \mathrm{E}$ & 434 & $2012-2013$ & Cwb & Warm \\
\hline 27 & China & Grassland & $35^{\circ} 57^{\prime} \mathrm{N}, 104^{\circ} 08^{\prime} \mathrm{E}$ & 386 & 2007-2012 & Dwb & Snow and polar \\
\hline 28 & China & Grassland & $38^{\circ} 03^{\prime} \mathrm{N}, 100^{\circ} 28^{\prime} \mathrm{E}$ & 556.6 & 2013-2015 & ET & Snow and polar \\
\hline
\end{tabular}


Table A1. Cont.

\begin{tabular}{|c|c|c|c|c|c|c|c|}
\hline Code & Country & $\begin{array}{c}\text { Vegetation } \\
\text { Type }\end{array}$ & Locations & $\begin{array}{c}\text { ET } \\
(\mathrm{mm} / \text { Year })\end{array}$ & Period & $\begin{array}{l}\text { Köppen } \\
\text { Climate }^{1}\end{array}$ & $\begin{array}{c}\text { Modified } \\
\text { Climate Zone } \\
\text { Used in This } \\
\text { Study }\end{array}$ \\
\hline 29 & China & Grassland & $38^{\circ} 25^{\prime} \mathrm{N}, 98^{\circ} 19^{\prime} \mathrm{E}$ & 270.6 & 2011 & ET & Snow and polar \\
\hline 30 & China & Grassland & $37^{\circ} 36^{\prime} \mathrm{N}, 101^{\circ} 18^{\prime} \mathrm{E}$ & 390 & 2002-2005 & BSk & Warm \\
\hline 31 & China & Grassland & $31^{\circ} 39^{\prime} \mathrm{N}, 92^{\circ} 01^{\prime} \mathrm{E}$ & 417 & $2014 / 2017$ & $\mathrm{ET}$ & Snow and polar \\
\hline 32 & China & Grassland & $34^{\circ} 24^{\prime} \mathrm{N}, 100^{\circ} 24^{\prime} \mathrm{E}$ & 505.65 & 2007-2008 & Dwc & Snow and polar \\
\hline 33 & China & Grassland & $37^{\circ} 40^{\prime} \mathrm{N}, 101^{\circ} 20^{\prime} \mathrm{E}$ & 420.2 & $2002-2005$ & BSk & Warm \\
\hline 34 & China & Grassland & $30^{\circ} 51^{\prime} \mathrm{N}, 91^{\circ} 05^{\prime} \mathrm{E}$ & 495.55 & 2004-2005 & ET & Snow and polar \\
\hline 35 & China & $\mathrm{NF}^{3}$ & $26^{\circ} 44^{\prime} \mathrm{N}, 115^{\circ} 03^{\prime} \mathrm{E}$ & 787 & 2003-2010 & Cfa & Warm \\
\hline 36 & Japan & $\mathrm{NF}^{3}$ & $34^{\circ} 58^{\prime} \mathrm{N}, 136^{\circ} 00^{\prime} \mathrm{E}$ & 752 & 2001-2007 & Cfa & Warm \\
\hline 37 & Japan & $\mathrm{NF}^{3}$ & $42^{\circ} 44^{\prime} \mathrm{N}, 141^{\circ} 31^{\prime} \mathrm{E}$ & 494 & $2002-2003$ & $\mathrm{Dfb}$ & Snow and polar \\
\hline 38 & China & MV & $40^{\circ} 22^{\prime} \mathrm{N}, 115^{\circ} 56^{\prime} \mathrm{E}$ & 580.75 & 2006-2009 & Dwb & Snow and polar \\
\hline 39 & China & MV & $42^{\circ} 24^{\prime} \mathrm{N}, 128^{\circ} 05^{\prime} \mathrm{E}$ & 525 & 2005-2007 & Dwb & Snow and polar \\
\hline
\end{tabular}

${ }^{1}$ Köppen Climate code: the letters A, B, C, D and E indicate the main climates, the letters $\mathrm{W}, \mathrm{S}, \mathrm{f}, \mathrm{s}, \mathrm{w}$ and $\mathrm{m}$ indicate the precipitation, and the codes $\mathrm{h}, \mathrm{k}, \mathrm{a}, \mathrm{b}, \mathrm{c}, \mathrm{d}, \mathrm{F}$ and $\mathrm{T}$ indicate the temperature. A: equatorial, B: arid, C: warm temperate, D: snow, E: polar, W: desert, S: steppe, f: fully humid, s: summer dry, w: winter dry, $\mathrm{m}$ : monsoonal, h: hot arid, k: cold arid, a: hot summer, b: warm summer, c: cool summer, d: extremely continental, F: polar frost, T: polar tundra.; ${ }^{2}$ The precise location is not available, but it can be inferred in the map of literature (https:/ / doi.org/10.1093/treephys/28.3.425 (accessed on 6 August 2021)).; ${ }^{3}$ NF indicates needleleaf forests.

\section{References}

1. Oki, T.; Kanae, S. Global hydrological cycles and world water resources. Science 2006, 313, 1068-1072. [CrossRef]

2. Lettenmaier, D.P.; Famiglietti, J.S. Hydrology-Water from on high. Nature 2006, 444, 562-563. [CrossRef]

3. Jung, M.; Reichstein, M.; Ciais, P.; Seneviratne, S.I.; Sheffield, J.; Goulden, M.L.; Bonan, G.; Cescatti, A.; Chen, J.; de Jeu, R.; et al. Recent decline in the global land evapotranspiration trend due to limited moisture supply. Nature 2010, 467, 951-954. [CrossRef] [PubMed]

4. Michel, D.; Jiménez, C.; Miralles, D.G.; Jung, M.; Hirschi, M.; Ershadi, A.; Martens, B.; McCabe, M.F.; Fisher, J.B.; Mu, Q.; et al. The WACMOS-ET project-Part 1: Tower-scale evaluation of four remote-sensing-based evapotranspiration algorithms. Hydrol. Earth Syst. Sci. 2016, 20, 803-822. [CrossRef]

5. Allen, R.G.; Pereira, L.S.; Raes, D.; Smith, M. Crop Evapotranspiration-Guidelines for Computing Crop Water Requirements-FAO Irrigation and Drainage Paper 56; FAO: Rome, Italy, 1998; p. D05109.

6. Raoufi, R.; Beighley, E. Estimating daily global evapotranspiration using Penman-Monteith equation and remotely sensed land surface temperature. Remote Sens. 2017, 9, 1138. [CrossRef]

7. Gan, R.; Zhang, Y.; Shi, H.; Yang, Y.; Eamus, D.; Cheng, L.; Chiew, F.H.S.; Yu, Q. Use of satellite leaf area index estimating evapotranspiration and gross assimilation for Australian ecosystems. Ecohydrology 2018, 11, e1974. [CrossRef]

8. Chen, Y.; Wang, S.; Ren, Z.; Huang, J.; Wang, X.; Liu, S.; Deng, H.; Lin, W. Increased evapotranspiration from land cover changes intensified water crisis in an arid river basin in northwest China. J. Hydrol. 2019, 574, 383-397. [CrossRef]

9. Zhang, Y.; Kong, D.; Gan, R.; Chiew, F.H.S.; McVicar, T.R.; Zhang, Q.; Yang, Y. Coupled estimation of $500 \mathrm{~m}$ and 8-day resolution global evapotranspiration and gross primary production in 2002-2017. Remote Sens. Environ. 2019, 222, 165-182. [CrossRef]

10. Yuan, L.; Ma, Y.; Chen, X.; Wang, Y.; Li, Z. An enhanced MOD16 evapotranspiration model for the Tibetan Plateau during the unfrozen season. J. Geophys. Res. Atmos. 2021, 126, e2020JD032787. [CrossRef]

11. Mu, Q.; Zhao, M.; Running, S.W. Improvements to a MODIS global terrestrial evapotranspiration algorithm. Remote Sens. Environ. 2011, 115, 1781-1800. [CrossRef]

12. Zhang, Y.; Peña-Arancibia, J.L.; McVicar, T.R.; Chiew, F.H.S.; Vaze, J.; Liu, C.; Lu, X.; Zheng, H.; Wang, Y.; Liu, Y.Y.; et al. Multi-decadal trends in global terrestrial evapotranspiration and its components. Sci. Rep. 2016, 6, 19124. [CrossRef] [PubMed]

13. Li, X.; He, Y.; Zeng, Z.; Lian, X.; Wang, X.; Du, M.; Jia, G.; Li, Y.; Ma, Y.; Tang, Y.; et al. Spatiotemporal pattern of terrestrial evapotranspiration in China during the past thirty years. Agric. For. Meteorol. 2018, 259, 131-140. [CrossRef]

14. Li, Z.; Zhang, Y.; Wang, S.; Yuan, G.; Yang, Y.; Cao, M. Evapotranspiration of a tropical rain forest in Xishuangbanna, southwest China. Hydrol. Processes 2010, 24, 2405-2416. [CrossRef]

15. Thornthwaite, C.W.; Holzman, B. The determination of evaporation from land and water surfaces. Mon. Weather Rev. 1939, 67, 4-11. [CrossRef]

16. Monteith, J.L. Evaporation and environment. Symp. Soc. Exp. Biol. 1965, 19, 205-234.

17. Gentilucci, M.; Bufalini, M.; Materazzi, M.; Barbieri, M.; Aringoli, D.; Farabollini, P.; Pambianchi, G. Calculation of potential evapotranspiration and calibration of the Hargreaves Equation using geostatistical methods over the Last 10 Years in Central Italy. Geosciences 2021, 11, 348. [CrossRef] 
18. Yao, Y.; Liang, S.; Cheng, J.; Liu, S.; Fisher, J.B.; Zhang, X.; Jia, K.; Zhao, X.; Qin, Q.; Zhao, B.; et al. MODIS-driven estimation of terrestrial latent heat flux in China based on a modified Priestley-Taylor algorithm. Agric. For. Meteorol. 2013, 171-172, 187-202. [CrossRef]

19. Priestley, C.; Taylor, R. On the assessment of surface heat flux and evaporation using large-scale parameters. Mon. Weather Rev. 1972, 100, 81-92. [CrossRef]

20. Yang, Y.; Su, H.; Zhang, R.; Tian, J.; Li, L. An enhanced two-source evapotranspiration model for land (ETEML): Algorithm and evaluation. Remote Sens. Environ. 2015, 168, 54-65. [CrossRef]

21. Tang, R.; Li, Z.-L.; Tang, B. An application of the T-s-VI triangle method with enhanced edges determination for evapotranspiration estimation from MODIS data in and and semi-arid regions: Implementation and validation. Remote Sens. Environ. 2010, 114, 540-551. [CrossRef]

22. Zeng, Z.; Piao, S.; Lin, X.; Yin, G.; Peng, S.; Ciais, P.; Myneni, R.B. Global evapotranspiration over the past three decades: Estimation based on the water balance equation combined with empirical models. Environ. Res. Lett. 2012, 7, 014026. [CrossRef]

23. Miralles, D.G.; Holmes, T.R.H.; De Jeu, R.A.M.; Gash, J.H.; Meesters, A.G.C.A.; Dolman, A.J. Global land-surface evaporation estimated from satellite-based observations. Hydrol. Earth Syst. Sci. 2011, 15, 453-469. [CrossRef]

24. Martens, B.; Miralles, D.G.; Lievens, H.; van der Schalie, R.; de Jeu, R.A.M.; Fernández-Prieto, D.; Beck, H.E.; Dorigo, W.A.; Verhoest, N.E.C. GLEAM v3: Satellite-based land evaporation and root-zone soil moisture. Geosci. Model Dev. 2017, 10, 1903-1925. [CrossRef]

25. Leuning, R.; Zhang, Y.; Rajaud, A.; Cleugh, H.; Tu, K. A simple surface conductance model to estimate regional evaporation using MODIS leaf area index and the Penman-Monteith equation. Water Resour. Res. 2008, 44. [CrossRef]

26. Mu, Q.; Heinsch, F.A.; Zhao, M.; Running, S.W. Development of a global evapotranspiration algorithm based on MODIS and global meteorology data. Remote Sens. Environ. 2007, 111, 519-536. [CrossRef]

27. Ryu, Y.; Baldocchi, D.D.; Kobayashi, H.; van Ingen, C.; Li, J.; Black, T.A.; Beringer, J.; van Gorsel, E.; Knohl, A.; Law, B.E.; et al Integration of MODIS land and atmosphere products with a coupled-process model to estimate gross primary productivity and evapotranspiration from $1 \mathrm{~km}$ to global scales. Glob. Biogeochem. Cycle 2011, 25. [CrossRef]

28. Yao, Y.; Liang, S.; Li, X.; Hong, Y.; Fisher, J.B.; Zhang, N.; Chen, J.; Cheng, J.; Zhao, S.; Zhang, X.; et al. Bayesian multimodel estimation of global terrestrial latent heat flux from eddy covariance, meteorological, and satellite observations. J. Geophys. Res.-Atmos. 2014, 119, 4521-4545. [CrossRef]

29. Wu, J.; Lakshmi, V.; Wang, D.; Lin, P.; Pan, M.; Cai, X.; Wood, E.F.; Zeng, Z. The reliability of global remote sensing evapotranspiration products over Amazon. Remote Sens. 2020, 12, 2211. [CrossRef]

30. Yin, L.; Wang, X.; Feng, X.; Fu, B.; Chen, Y. A comparison of SSEBop-Model-Based evapotranspiration with eight evapotranspiration products in the Yellow River Basin, China. Remote Sens. 2020, 12, 2528. [CrossRef]

31. Liu, Y.; Yang, Z.; Lin, P.; Zheng, Z.; Xie, S. Comparison and evaluation of multiple land surface products for the water budget in the Yellow River Basin. J. Hydrol. 2020, 584, 124534. [CrossRef]

32. Zheng, C.; Jia, L.; Hu, G.; Lu, J. Earth observations-based evapotranspiration in Northeastern Thailand. Remote Sens. 2019, 11, 138. [CrossRef]

33. Jiang, C.; Ryu, Y. Multi-scale evaluation of global gross primary productivity and evapotranspiration products derived from Breathing Earth System Simulator (BESS). Remote Sens. Environ. 2016, 186, 528-547. [CrossRef]

34. Li, S.; Wang, G.; Sun, S.; Chen, H.; Bai, P.; Zhou, S.; Huang, Y.; Wang, J.; Deng, P. Assessment of Multi-Source evapotranspiration products over China using eddy covariance observations. Remote Sens. 2018, 10, 1692. [CrossRef]

35. Ershadi, A.; McCabe, M.F.; Evans, J.P.; Chaney, N.W.; Wood, E.F. Multi-site evaluation of terrestrial evaporation models using FLUXNET data. Agric. For. Meteorol. 2014, 187, 46-61. [CrossRef]

36. Khan, M.S.; Liaqat, U.W.; Baik, J.; Choi, M. Stand-alone uncertainty characterization of GLEAM, GLDAS and MOD16 evapotranspiration products using an extended triple collocation approach. Agric. For. Meteorol. 2018, 252, 256-268. [CrossRef]

37. Zhao, Y.; Lu, Z.; Wei, Y. An Assessment of Global Precipitation and Evapotranspiration Products for Regional Applications. Remote Sens. 2019, 11, 1077. [CrossRef]

38. Wang, L.; Wu, B.; Elnashar, A.; Zeng, H.; Zhu, W.; Yan, N. Synthesizing a regional territorial evapotranspiration dataset for Northern China. Remote Sens. 2021, 13, 1076. [CrossRef]

39. Yang, X.; Yong, B.; Ren, L.; Zhang, Y.; Long, D. Multi-scale validation of GLEAM evapotranspiration products over China via ChinaFLUX ET measurements. Int. J. Remote Sens. 2017, 38, 5688-5709. [CrossRef]

40. Gao, X.; Gu, F.; Gong, D.; Hao, W.; Chu, J.; Li, H. Comparison of three evapotranspiration models in a rain-fed spring maize filed in the Loess Plateau, China. J. Agric. Meteorol. 2020, 76, 155-163. [CrossRef]

41. Chu, H.; Luo, X.; Ouyang, Z.; Chan, W.S.; Dengel, S.; Biraud, S.C.; Torn, M.S.; Metzger, S.; Kumar, J.; Arain, M.A.; et al. Representativeness of Eddy-Covariance flux footprints for areas surrounding AmeriFlux sites. Agric. For. Meteorol. 2021, 301-302, 108350. [CrossRef]

42. Sun, R.; Duan, Q.; Wang, J. Understanding the spatial patterns of evapotranspiration estimates from land surface models over China. J. Hydrol. 2021, 595, 126021. [CrossRef]

43. Sriwongsitanon, N.; Suwawong, T.; Thianpopirug, S.; Williams, J.; Jia, L.; Bastiaanssen, W. Validation of seven global remotely sensed ET products across Thailand using water balance measurements and land use classifications. J. Hydrol. Reg. Stud. 2020, 30, 100709. [CrossRef] 
44. Yun, X.; Tang, Q.; Li, J.; Lu, H.; Zhang, L.; Chen, D. Can reservoir regulation mitigate future climate change induced hydrological extremes in the Lancang-Mekong River Basin? Sci. Total Environ. 2021, 785, 147322. [CrossRef]

45. Wei, J.; Wei, Y.; Tian, F.; Nott, N.; de Wit, C.; Guo, L.; Lu, Y. News media coverage of conflict and cooperation dynamics of water events in the Lancang-Mekong River basin. Hydrol. Earth Syst. Sci. 2021, 25, 1603-1615. [CrossRef]

46. Li, D.; Zhao, J.; Govindaraju, R.S. Water benefits sharing under transboundary cooperation in the Lancang-Mekong River Basin. J. Hydrol. 2019, 577, 123989. [CrossRef]

47. Gao, J.; Zhao, J.; Wang, H. Dam-Impacted Water-Energy-Food Nexus in Lancang-Mekong River Basin. J. Water Resour. Plan. Manag. 2021, 147, 04021010. [CrossRef]

48. Sulla-Menashe, D.; Gray, J.M.; Abercrombie, S.P.; Friedl, M.A. Hierarchical mapping of annual global land cover 2001 to present: The MODIS Collection 6 Land Cover product. Remote Sens. Environ. 2019, 222, 183-194. [CrossRef]

49. Lahiri, S.N. Resampling methods for spatial data. In Resampling Methods for Dependent Data; Springer: New York, NY, USA, 2003; pp. 281-338.

50. Gao, W. Applications of solutions to non-linear energy budget equations. Agric. For. Meteorol. 1988, 43, 121-145. [CrossRef]

51. Yuan, W.; Liu, S.; Yu, G.; Bonnefond, J.-M.; Chen, J.; Davis, K.; Desai, A.R.; Goldstein, A.H.; Gianelle, D.; Rossi, F.; et al. Global estimates of evapotranspiration and gross primary production based on MODIS and global meteorology data. Remote Sens. Environ. 2010, 114, 1416-1431. [CrossRef]

52. Fisher, J.B.; Tu, K.P.; Baldocchi, D.D. Global estimates of the land-atmosphere water flux based on monthly AVHRR and ISLSCP-II data, validated at 16 FLUXNET sites. Remote Sens. Environ. 2008, 112, 901-919. [CrossRef]

53. Wang, K.; Dickinson, R.E.; Wild, M.; Liang, S. Evidence for decadal variation in global terrestrial evapotranspiration between 1982 and 2002: 2. Results. J. Geophys. Res.-Atmos. 2010, 115. [CrossRef]

54. Kim, W.; Hyeongho, S.; Komori, D.; Jaeil, C. Characteristics of the relative sampling error and its application to flux aggregation in eddy covariance measurements. J. Agric. Meteorol. 2020, 76, 89-95. [CrossRef]

55. Kim, W.; Miyata, A.; Ashraf, A.; Maruyama, A.; Chidthaisong, A.; Jaikaeo, C.; Komori, D.; Ikoma, E.; Sakurai, G.; Seoh, H.-H.; et al. FluxPro as a realtime monitoring and surveilling system for eddy covariance flux measurement. J. Agric. Meteorol. 2015, 71, 32-50. [CrossRef]

56. Wohlfahrt, G.; Haslwanter, A.; Hörtnagl, L.; Jasoni, R.L.; Fenstermaker, L.F.; Arnone, J.A.; Hammerle, A. On the consequences of the energy imbalance for calculating surface conductance to water vapour. Agric. For. Meteorol. 2009, 149, 1556-1559. [CrossRef] [PubMed]

57. Qi, D.; Yang, D.; Song, Q.; Liu, Y.; Zhang, Y.; Fei, X.; Sha, L.; Zhou, W.; Chen, A.; Wen, G.; et al. An observation dataset of carbon and water fluxes at Yuanjiang Dry-hot Valley Ecological Station (2013-2015). China Sci. Data 2021, 6, 110-122. [CrossRef]

58. Qi, D.; Zhang, Y.; Song, Q.; Fei, X.; Sha, L.; Liu, Y.; Zhou, W.; Zhou, L.; Deng, X.; Luo, Y.; et al. A dataset of carbon, water and energy fluxes observed in Xishuangbanna tropical seasonal rain forest from 2003 to 2010. China Sci. Data 2021, 6, 37-49. [CrossRef]

59. Qi, D.; Fei, X.; Song, Q.; Zhang, Y.; Sha, L.; Liu, Y.; Zhou, W.; Lu, Z.; Fan, Z. A dataset of carbon and water fluxes observation in subtropical evergreen broad-leaved forest in Ailao Shan from 2009 to 2013. China Sci. Data 2021, 6, 87-97. [CrossRef]

60. Yu, H.; Qi, D.; Zhang, Y.; Sha, L.; Liu, Y.; Zhou, W.; Deng, Y.; Song, Q. An observation dataset of carbon and water fluxes in Xishuangbanna rubber plantations from 2010 to 2014. China Sci. Data 2021, 6, 98-109. [CrossRef]

61. Gomis-Cebolla, J.; Jimenez, J.C.; Sobrino, J.A.; Corbari, C.; Mancini, M. Intercomparison of remote-sensing based evapotranspiration algorithms over amazonian forests. Int. J. Appl. Earth Obs. Geoinf. 2019, 80, 280-294. [CrossRef]

62. Idso, S.B.; Jackson, R.D. Thermal radiation from the atmosphere. J. Geophys. Res. 1969, 74, 5397-5403. [CrossRef]

63. Prata, A.J. A new long-wave formula for estimating downward clear-sky radiation at the surface. Q. J. R. Meteorol. Soc. 1996, 122, 1127-1151. [CrossRef]

64. Obermeier, W.A.; Lehnert, L.W.; Kammann, C.I.; Müller, C.; Grünhage, L.; Luterbacher, J.; Erbs, M.; Moser, G.; Seibert, R.; Yuan, N.; et al. Reduced CO2 fertilization effect in temperate C3 grasslands under more extreme weather conditions. Nat. Clim. Chang. 2017, 7, 137-141. [CrossRef]

65. Jiang, M.; Zaehle, S.; De Kauwe, M.G.; Walker, A.P.; Caldararu, S.; Ellsworth, D.S.; Medlyn, B.E. The quasi-equilibrium framework revisited: Analyzing long-term CO2 enrichment responses in plant-soil models. Geosci. Model Dev. 2019, 12, 2069-2089. [CrossRef]

66. Hakamada, R.E.; Hubbard, R.M.; Stape, J.L.; Lima, W.d.P.; Moreira, G.G.; Ferraz, S.F.d.B. Stocking effects on seasonal tree transpiration and ecosystem water balance in a fast-growing Eucalyptus plantation in Brazil. For. Ecol. Manag. 2020, 466, 118149. [CrossRef]

67. Liu, H.; Zhang, Q.; Katul, G.G.; Cole, J.J.; Chapin, F.S.; MacIntyre, S. Large CO2 effluxes at night and during synoptic weather events significantly contribute to CO2 emissions from a reservoir. Environ. Res. Lett. 2016, 11, 064001. [CrossRef]

68. Ball, J.T.; Woodrow, I.E.; Berry, J.A. A model predicting stomatal conductance and its contribution to the control of photosynthesis under different environmental conditions. In Progress in Photosynthesis Research: Volume 4, Proceedings of the VIIth International Congress on Photosynthesis Providence, Rhode Island, USA, 10-15 August 1986; Biggins, J., Ed.; Springer: Dordrecht, The Netherlands, 1987; pp. 221-224.

69. Wakamatsu, A.; Mori, I.C.; Matsuura, T.; Taniwaki, Y.; Ishii, R.; Yoshida, R. Possible roles for phytohormones in controlling the stomatal behavior of Mesembryanthemum crystallinum during the salt-induced transition from C3 to crassulacean acid metabolism. J. Plant Physiol. 2021, 262, 153448. [CrossRef] [PubMed] 
70. Eller, F.; Jensen, K.; Reisdorff, C. Nighttime stomatal conductance differs with nutrient availability in two temperate floodplain tree species. Tree Physiol. 2016, 37, 428-440. [CrossRef] [PubMed]

71. Hoshika, Y.; De Carlo, A.; Baraldi, R.; Neri, L.; Carrari, E.; Agathokleous, E.; Zhang, L.; Fares, S.; Paoletti, E. Ozone-induced impairment of night-time stomatal closure in O3-sensitive poplar clone is affected by nitrogen but not by phosphorus enrichment. Sci. Total Environ. 2019, 692, 713-722. [CrossRef] [PubMed]

72. Eder, F.; De Roo, F.; Rotenberg, E.; Yakir, D.; Schmid, H.P.; Mauder, M. Secondary circulations at a solitary forest surrounded by semi-arid shrubland and their impact on eddy-covariance measurements. Agric. For. Meteorol. 2015, 211-212, 115-127. [CrossRef]

73. Xu, Z.; Ma, Y.; Liu, S.; Shi, W.; Wang, J. Assessment of the energy balance blosure under advective conditions and Its impact using remote sensing data. J. Appl. Meteorol. Climatol. 2017, 56, 127-140. [CrossRef]

74. Liu, S.M.; Xu, Z.W.; Wang, W.Z.; Jia, Z.Z.; Zhu, M.J.; Bai, J.; Wang, J.M. A comparison of eddy-covariance and large aperture scintillometer measurements with respect to the energy balance closure problem. Hydrol. Earth Syst. Sci. 2011, 15, 1291-1306. [CrossRef]

75. Falge, E.; Baldocchi, D.; Olson, R.; Anthoni, P.; Aubinet, M.; Bernhofer, C.; Burba, G.; Ceulemans, R.; Clement, R.; Dolman, H.; et al. Gap filling strategies for defensible annual sums of net ecosystem exchange. Agric. For. Meteorol. 2001, 107, 43-69. [CrossRef]

76. Du, Q.; Liu, H.; Liu, Y.; Xu, L.; Sun, J. Water and carbon dioxide fluxes over a "floating blanket" wetland in southwest of China with eddy covariance method. Agric. For. Meteorol. 2021, 311, 108689. [CrossRef]

77. Irvin, J.; Zhou, S.; McNicol, G.; Lu, F.; Liu, V.; Fluet-Chouinard, E.; Ouyang, Z.; Knox, S.H.; Lucas-Moffat, A.; Trotta, C.; et al. Gapfilling eddy covariance methane fluxes: Comparison of machine learning model predictions and uncertainties at FLUXNET-CH4 wetlands. Agric. For. Meteorol. 2021, 308-309, 108528. [CrossRef]

78. El Maayar, M.; Chen, J.M.; Price, D.T. On the use of field measurements of energy fluxes to evaluate land surface models. Ecol. Model. 2008, 214, 293-304. [CrossRef]

79. Yue, P.; Zhang, Q.; Zhang, L.; Li, H.; Yang, Y.; Zeng, J.; Wang, S. Long-term variations in energy partitioning and evapotranspiration in a semiarid grassland in the Loess Plateau of China. Agric. For. Meteorol. 2019, 278, 107671. [CrossRef]

80. Liu, H.; Randerson, J.T.; Lindfors, J.; Massman, W.J.; Foken, T. Consequences of incomplete surface energy balance closure for CO2 fluxes from Open-Path CO2/H2O infrared gas analysers. Bound.-Layer Meteorol. 2006, 120, 65-85. [CrossRef]

81. Barr, A.G.; King, K.M.; Gillespie, T.J.; Den Hartog, G.; Neumann, H.H. A comparison of bowen ratio and eddy correlation sensible and latent heat flux measurements above deciduous forest. Bound.-Layer Meteorol. 1994, 71, 21-41. [CrossRef]

82. Blanken, P.D.; Black, T.A.; Yang, P.C.; Neumann, H.H.; Nesic, Z.; Staebler, R.; den Hartog, G.; Novak, M.D.; Lee, X. Energy balance and canopy conductance of a boreal aspen forest: Partitioning overstory and understory components. J. Geophys. Res.-Atmos. 1997, 102, 28915-28927. [CrossRef]

83. Perez, P.J.; Castellvi, F.; Ibañez, M.; Rosell, J.I. Assessment of reliability of Bowen ratio method for partitioning fluxes. Agric. For Meteorol. 1999, 97, 141-150. [CrossRef]

84. Castellví, F.; Snyder, R.L.; Baldocchi, D.D. Surface energy-balance closure over rangeland grass using the eddy covariance method and surface renewal analysis. Agric. For. Meteorol. 2008, 148, 1147-1160. [CrossRef]

85. Sánchez, J.M.; Caselles, V.; Niclòs, R.; Coll, C.; Kustas, W.P. Estimating energy balance fluxes above a boreal forest from radiometric temperature observations. Agric. For. Meteorol. 2009, 149, 1037-1049. [CrossRef]

86. Tavella, P.; Premoli, A. Estimating the instabilities of N clocks by measuring differences of their readings. Metrologia 1994, 30, 479-486. [CrossRef]

87. Wang, S. Simulation of evapotranspiration and its response to plant water and CO2 transfer dynamics. J. Hydrometeorol. 2008, 9 , 426-443. [CrossRef]

88. Liang, J.; Yang, Z.; Cai, X.; Lin, P.; Zheng, H.; Bian, Q. Modeling the impacts of nitrogen dynamics on regional terrestrial carbon and water cycles over China with Noah-MP-CN. Adv. Atmos. Sci. 2020, 37, 679-695. [CrossRef]

89. Piyoosh, A.K.; Ghosh, S.K. Effect of autocorrelation on temporal trends in rainfall in a valley region at the foothills of Indian Himalayas. Stoch. Environ. Res. Risk Assess. 2017, 31, 2075-2096. [CrossRef] 